Universidade de Brasília

Faculdade de Direito

O problema do enquadramento sindical dos trabalhadores terceirizados: incompatibilidade entre a liberdade sindical e o princípio da unicidade. 
Daniel Sales Vaz

\section{O problema do enquadramento sindical dos trabalhadores terceirizados: incompatibilidade entre a liberdade sindical e o princípio da unicidade.}

Monografia apresentada a Faculdade de Direito da Universidade de Brasília (UnB), como requisito à obtenção do título de Bacharel em Direito.

Orientador: Prof. Doutorando. Ricardo Machado Lourenço Filho

Brasília

2011 
Após sessão pública de defesa desta Monografia, o candidato foi considerado aprovado pela Banca Examinadora.

Prof. Doutorando Ricardo Machado Lourenço Filho Orientador

\begin{tabular}{c}
\hline Renato Bigliazzi/Doutorando \\
Membro \\
\\
\hline Aline Lisboa Guimarães/Mestre \\
Membro
\end{tabular}

Brasília, 23 de Dezembro de 2011. 


\section{Resumo}

A presente monografia aduz, inicialmente, o aspecto crítico que se encontra o mundo do trabalho, ressaltando a relação entre a terceirização e o sindicalismo. Neste intento, tal problema é encarado no aspecto de se investigar como a figura dos trabalhadores terceirizados desafia e coloca em questão a sistemática de enquadramento sindical. Com esta perspectiva, têm-se como foco de investigação os impactos da terceirização na conformação do sindicalismo, demonstrando suas deficiências no que tange à representatividade dos trabalhadores. Sendo assim, a presente monografia tem por intuito mostrar a importância de se reconhecer a liberdade sindical como direito fundamental, com vistas a propiciar o incremento reivindicativo dos trabalhadores. Deste modo, a presente pesquisa terá por pressuposto a necessidade de se reconhecer a liberdade sindical como direito fundamental, caracterizando-a como elemento essencial para a conformação de um contexto democrático no seio sindical. Este objetivo será relevante no sentido de se saber quais alternativas se revelam para a encruzilhada jurídica e social do trabalho, notadamente no que tange ao enquadramento sindical dos trabalhadores terceirizados. O importante é notar que a crise faz parte da renovação de qualquer sistema social, sendo um processo contínuo de relação entre as bases do sistema e a dinâmica social, num constante processo evolucionista. Sendo assim, será possível verificar que a crise é algo inerente à estruturação do sistema jurídico, denunciando a formação constante de paradoxos, destacando-se, entre eles, o existente no art. $8^{\circ}$ da Constituição Federal, no qual se encontra presente o embate entre o princípio da liberdade sindical e o princípio da unicidade. Em que se faz necessário a "desparadoxação" como forma de estabilização jurídica. Assim, em face desse processo, propugna-se, neste trabalho, a preponderância da liberdade sindical em face da unicidade, denunciando este como anacronismo constitucional, dado o novo contexto social em que está inserto o trabalhador. Desta forma, como se pretende asseverar, a eleição da liberdade sindical como direito fundamental é essencial para o fortalecimento sindical, dando mais representatividade ao trabalhador terceirizado para fazer frente à força do capital. Assim sendo, o eixo da presente monografia está na adoção da liberdade sindical como direito fundamental, no que se tentará demonstrar ser uma aquisição evolutiva do direito, já que esta concepção informa um sentido mais abstrato, ou seja, mais apto a lidar com a crescente complexidade do mundo sindical. 
Palavras chaves: enquadramento sindical; terceirização; princípio da unicidade; liberdade sindical; direitos fundamentais; sindicalismo. 


\section{Sumário}

Introdução

Capítulo I: O problema do enquadramento sindical dos trabalhadores terceirizados 10

1.1 O anacrônico princípio da unicidade e o enquadramento sindical dos trabalhadores terceirizados

$1.2 \mathrm{O}$ problema do enquadramento sindical dos trabalhadores terceirizados

Capítulo II: A liberdade sindical como direito fundamental

2.1 A liberdade sindical como direito fundamental: a democracia como elevada taxa de complexidade social

2.2 A liberdade sindical como fator de representatividade e de dinamismo reivindicativo dos trabalhadores terceirizados. 


\section{Introdução}

Entre muitos aspectos a se tratar sobre o mundo do trabalho, coloca-se em destaque, inicialmente, a crise trabalhista em face do impulso precarizante da terceirização, tendo por objetivo precípuo perquirir suas implicações nas organizações sindicais. O problema a ser tratado, portanto, é que a figura dos trabalhadores terceirizados desafia e coloca em questão a estrutura jurídica de regulação das relações trabalhistas.

Com esta perspectiva, têm-se como foco de investigação os impactos da terceirização na conformação do sindicalismo, demonstrando suas deficiências no que tange à representatividade dos trabalhadores. Nesta perspectiva, a presente monografia tem por intuito demonstrar a importância de se reconhecer a liberdade sindical como direito fundamental, com vistas a propiciar o incremento reivindicativo dos trabalhadores.

A presente pesquisa, portanto, terá por pressuposto a necessidade de se reconhecer a liberdade sindical como direito fundamental, caracterizando-a como elemento essencial para a conformação de um contexto democrático no seio sindical, rechaçando e denunciando o anacronismo do princípio da unicidade.

A perquirição terá por objetivo identificar quais as implicações da terceirização no mundo trabalhista, tendo por destaque, além da precarização do obreiro, a desarticulação sindical. A constatação disso será relevante no sentido de se saber quais alternativas se apresentam para a encruzilhada jurídica e social do trabalho, notadamente no que tange ao enquadramento sindical dos trabalhadores terceirizados.

Será possível verificar que a crise é algo inerente à estruturação do sistema jurídico, denunciando a formação constante de paradoxos. A par deste paradoxo, portanto, será aduzida a contradição existente no art. $8^{\circ}$ da Constituição Federal, referente ao embate entre o princípio da liberdade sindical e o princípio da unicidade. Em que se demonstrará necessário a desparadoxação como forma de estabilização jurídica, dando relevo à liberdade.

Assim, neste processo, propugna-se neste trabalho a preponderância da liberdade sindical em face da unicidade, denunciando-a como princípio anacrônico em face dos avanços constitucionais, dado o novo contexto social em que o trabalhador está inserido. 
Desta forma, como se pretende asseverar, a eleição da liberdade sindical como direito fundamental é essencial para o fortalecimento sindical, dando mais representatividade ao trabalhador para fazer frente aos ditames do capital.

Assim sendo, como se pretende demonstrar, sob a perspectiva da teoria dos sistemas, a adoção da liberdade sindical como direito fundamental é uma aquisição evolutiva do direito, já que esta concepção informa um sentido mais abstrato, ou seja, mais apto a estabilizar as múltiplas expectativas.

Antes, entretanto, de compreender a fundo tal fenômeno, o presente trabalho tem por foco a terceirização de mão-de-obra e suas implicações na organização sindical, dando realce ao problema de enquadramento sindical dos trabalhadores terceirizados.

Calcado nessa tese, o presente trabalho tem por enfoque a flexibilização das regras de organização sindical a fim de possibilitar enquadramento sindical mais correlato com o dinamismo reivindicativo dos trabalhadores terceirizados.

Tal proposição terá por mira analisar a realidade sindical em face da crise que se instalou no mundo do trabalho, dando ênfase à prática da terceirização obreira. $\mathrm{O}$ que se revela sublinhar, sob este aspecto, é que a expansão dos poderes do capital nas relações coletivas de trabalho se consubstancia com a perda do sentimento de pertencimento a uma coletividade, com a conseqüente erosão da solidariedade, quebrando a lógica da ação coletiva. Ou seja, tal prática acaba, além de precarizar o trabalho, por desarticular a organização sindical.

Deste modo, sob a lógica de valorização dos direitos fundamentais dos trabalhadores, o presente texto aduzirá a liberdade sindical como direito fundamental, a fim de redirecionar o processo decisório do sistema jurídico, com vistas a propiciar melhor enquadramento sindical dos trabalhadores terceirizados.

Para tanto, ter-se-á por fundamento a teoria dos sistemas de Niklas Luhmann, na qual se aduzirá como característica do direito fundamental o seu grau de abstração e indeterminação. Assim, sob a perspectiva evolucionista da passagem de sentido concreto para o abstrato, propugnar-se-á como característica precípua da liberdade sindical como direito fundamental a capacidade de recrudescer a complexidade social, possibilitando mais alternativas de escolha por parte dos trabalhadores em suas organizações formais. Nessa perspectiva, portanto, sob a égide da liberdade sindical plena, tentar-se-á provar que a 
liberdade de escolha sindical possibilita mais dinamismo reivindicativo aos trabalhadores terceirizados, denunciando a obsolescência do atual processo de enquadramento sindical no que tange à representatividade. 


\section{O problema do enquadramento sindical dos trabalhadores terceirizados}

\section{$1.1 O$ anacrônico princípio da unicidade e o enquadramento sindical dos trabalhadores terceirizados}

A despeito das críticas direcionadas ao texto constitucional, não se pode olvidar que este progrediu em vários aspectos no que concerne à liberdade sindical. Entretanto, consoante ensinamento de Sayonara Grillo, "existem fortes razões para afirmar a permanência renovada de velhos institutos do corporativismo [...]" 1 O fato é que a Constituição, conquanto tenha avançado em direção à liberdade sindical, não se livrou por completo das influências do sistema corporativista. ${ }^{2}$

No mesmo sentido, suscita Trindade que “a Constituição de 1988 caminhou em direção à liberdade sindical," Todavia, aduz que esta "estabeleceu uma liberdade limitada, quando impôs a unicidade sindical, a sindicalização por categoria e a base territorial mínima (municipal)." 3

A Constituição, conforme ensinamento de Trindade, "embora consagre ser livre a associação sindical (art. $8^{\circ}$ ), não adota o regime da pluralidade sindical e não faculta a unidade sindical, mas, sim, impõe a unicidade sindical (inc. II do art. $8^{\circ}$ ), quando prescreve ser vedada a criação de mais de uma organização sindical [...]" Dentro dessa perspectiva, Sayonara Grillo aduz que "a partir de um exame das configurações reais do atual estágio das relações de trabalho no país é importante destacar que não se vive efetivamente em um regime de liberdade sindical." 4

À luz destes esclarecimentos, cabe aduzir um certo hibridismo da Constituição, pois, além de se orientar pela liberdade sindical, consigna regras restritivas, tendo por destaque a da unicidade. ${ }^{5}$

Assim, no dizer de Trindade, "a Constituição brasileira não estabelece uma liberdade absoluta, posto que, como disposição limitadora, impõe a unicidade sindical, a

\footnotetext{
${ }^{1}$ SILVA (2008a, p. 232)

${ }^{2}$ SILVA (2008a, p. 232)

3 TRINDADE (p. 19-20)

${ }^{4}$ SILVA (2008a, p. 232)

${ }^{5}$ SILVA (2008a, p. 233)
} 
sindicalização por categoria e a observância da base territorial mínima, conforme se observa no inciso II do art. $8^{\circ} .{ }^{6} \mathrm{O}$ fato é que, segundo este mesmo autor, "o enquadramento sindical previsto na Constituição importou restrição à liberdade sindical, impedindo o livre impulso associativo e o desenvolvimento natural dos sindicatos." 7

Esta aparente contradição, informada pelo hibridismo, não significa, segundo Sayonara Grillo, "que sob o aspecto da normatividade constitucional a liberdade sindical não seja um princípio jurídico estabelecido como estruturante do sistema normativo."

${ }^{8}$ Pelo contrário, como bem lembra Sayonara, "tais regras jurídicas [regras da unicidade e do imposto sindical], do ponto de vista constitucional, não suplantam nem esvaziam princípios e regras dotados de normatividade plena que assegurem a liberdade e a autonomia sindical." 9

Entretanto, embora se defenda a liberdade sindical como princípio informador do sistema jurídico, a prática do enquadramento sindical tem-se mostrado demasiado restritivo em relação a esta liberdade.

A par disso, vale notar, conforme Eduardo Santos, "que a figura do enquadramento sindical só existe no ordenamento jurídico como forma de viabilizar o cumprimento do princípio da Unicidade Sindical." 10

Com efeito, esta sistemática produz, juntamente com o aspecto dinâmico da terceirização, um mundo sindical muito conturbado no que tange ao enquadramento sindical, trazendo graves desajustes, principalmente para o trabalhador terceirizado.

Nessa perspectiva, severas críticas têm sido direcionadas à Constituição brasileira, pois, como enfatiza Trindade:

[...] instituindo um Estado Democrático de Direito (preâmbulo e art. $1^{\circ}$ ), admite o pluralismo político (inc. $\mathrm{V}$ do art. $1^{\circ}$ e art. 17) e religioso (art. $5^{\circ}$, VI), mas não permite, com a imposição da unicidade (vigorante apenas para a sindicalização no setor privado), o pluralismo sindical, mantendo, no particular, uma estrutura sindical não espontânea, antidemocrática, nascida de um Estado nitidamente autoritário e por ele imposta. ${ }^{11}$

Note-se que o princípio da unicidade representa postura retrógada, vez que revigora o sistema sindical corporativista precedente à promulgação da Constituição de

\footnotetext{
${ }^{6}$ TRINDADE (SD, p. 7)

7 TRINDADE (SD, p.7)

${ }^{8}$ SILVA (2008a, p. 232)

9 SILVA (2008a, p. 233)

${ }^{10}$ SANTOS (SD, p. 1)

${ }^{11}$ TRINDADE (SD, p. 20)
} 
1988. Isto é, embora se tenha empenhado para implementar a liberdade sindical como principio informador de uma nova sistemática sindical, a configuração do sistema de enquadramento sindical conforme a imposição de um sindicato único soa de forma autoritária, remetendo a pratica sindical a momentos obscuros da história brasileira.

A imposição contrária à liberdade sindical está no fato de não permitir aos trabalhadores escolher o sindicato que lhes convém, conforme observa Trindade:

[...] não se permite escolher o sindicato que os representará; não se tolera uma competitividade entre os sindicados, que ensejaria e asseguraria a avaliação da competência e idoneidade, garantindo ao representado avaliar os resultados reais obtidos pelo seu representante, e, em decorrência dessa avaliação livre, optar por renovar-lhe o mandato representativo ou suprimirlhe tal poder. ${ }^{12}$

Contudo, consoante pontua Sayonara Grillo, "a permanência de algumas modalidades organizativas do sistema confederativo precedente não foi o texto da Constituição em si, mas sim a ausência de novas regras infraconstitucionais que dêem conceituação jurídica diferente aos conceitos de categoria, sindicato [...]." ${ }^{13}$ Ou seja, pouco foi feito para que fosse efetivamente implementado os avanços constitucionais na prática do sindicalismo, dando ensejo ao retorno de modalidades organizativas tradicionais. ${ }^{14}$

Nessa perspectiva, para Sayonara Grillo, "um dos maiores fatores de preservação do sistema e esvaziamento das inovações anunciadas por ocasião da Constituinte são as interpretações construídas sobre o texto constitucional aprovado." ${ }^{15}$ Ou seja, a perspectiva de liberdade sindical foi comprometida quando da recepção, pelo texto constitucional, de dispositivos da CLT, no que tange especialmente ao critério de sindicalização a partir da definição de categorias econômica ou profissional específicas, isto é, dando ênfase à unicidade.

O que se verifica, contudo, é muita discussão doutrinária e jurisprudencial após a vigência da Constituição de 1988 sobre a recepção ou não de determinados artigos da CLT, persistindo ainda como polêmico, por exemplo, o art. 577 da CLT, por ser incompatível com a nova ordem constitucional. ${ }^{16}$

A par deste efeito, observa-se com perplexidade a confusão que o conceito de categoria tem ocasionado na identificação do sindicato correspondente. Ocorre

\footnotetext{
${ }^{12}$ TRINDADE (SD, p. 20)

${ }^{13}$ SILVA (2008a, p. 235)

${ }^{14}$ SILVA (2008a, p. 235)

${ }^{15}$ SILVA (2008a, p. 235)

${ }^{16}$ BENHAME (SD)
} 
que os trabalhadores acabam por sofrer com a problemática de identificar qual é o sindicato que tem legitimidade para representá-los, visto ser inarredável a aplicação do princípio da unicidade. $^{17}$

Ou seja, dado o conceito aberto de categoria, após a promulgação da Constituição de 1988, segundo proposição de Eduardo Santos, “o assunto enquadramento sindical vem causando muitas dúvidas na relação de trabalho, com grande impacto nos contratos de trabalho. A dúvida surge pela falta de parâmetros legais para que se faça o devido enquadramento sindical [...].", 18

Consoante o supracitado, Eduardo Santos adverte:

O problema do enquadramento sindical vem, por muito tempo trazendo prejuízos, tanto aos trabalhadores como para as empresas. Os trabalhadores em muitos casos, devido à ignorância e falta de interesse nas questões que tratam da coletividade, não sabem e não se preocupam em saber quem são os seus reais representantes, razão pela qual os trabalhadores em muitos casos, desconhecem as Convenções e Acordos Coletivos de Trabalho que devem fazer valer. Já a empresa, em certas situações por não saber qual entidade sindical lhe representa ou mesmo o sindicato que representa os seus trabalhadores, não sabe identificar qual Convenção Coletiva de Trabalho deve respeitar e aplicar em suas relações trabalhistas. ${ }^{19}$

O fato é que, como registra Trindade, "as categorias e as entidades sindicais são fatos sociais espontâneos, que dispensam as sua criação pelo Estado, a este cabe somente o reconhecimento do que existe na realidade econômica e social." ${ }^{20}$ Ou seja, a partir do momento que se tem por preconcebido determinado enquadramento como o certo, e surgem diversas possibilidades, dada vacuidade do conceito de categoria, instaura-se o problema de representatividade e do enquadramento sindical.

A dificuldade, portanto, é que a submissão a um enquadramento sindical restrito pela unicidade não coaduna com a liberdade sindical, visto não conferir aos trabalhadores o amplo direito de constituírem as organizações que acharem convenientes.

A sistemática do enquadramento sindical, portanto, com vistas a cumprir o princípio constitucional da unicidade, vem figurando, até o momento, como medida contraproducente, visto que ao invés de simplificar, tem tornado um tanto complexo o

\footnotetext{
${ }^{17}$ SANTOS (SD)

${ }^{18}$ SANTOS (SD)

${ }^{19}$ SANTOS (SD)

${ }^{20}$ TRINDADE (SD, p. 8)
} 
enquadramento dos trabalhadores, ocasionando o que Sayonara Grillo denomina "pluralidade sindical oblíqua." 21

Este quadro agrava-se ainda mais quando se tem em discussão o enquadramento sindical dos trabalhadores terceirizados, os quais se situam em posição mais distante no que se refere à identificação com determinada categoria profissional ou econômica, dada a relação trilateral que se conforma nas suas contratações. Ou seja, a confusão supracitada se torna ainda maior quando se procura delimitar o enquadramento sindical dos trabalhadores terceirizados. Esta circunstância traz, em seu cerne, um grave problema de representatividade sindical aos terceirizados, enfraquecendo suas organizações.

O que se nota é que, segundo Lívia Miraglia, a terceirização significa o "deslocamento jurídico do contrato de trabalho da empresa tomadora para a empresa terceira prestadora de serviços." 22 Ou seja, em termos mais simples, a terceirização, segundo Viana, "corrompe o próprio conceito de empregador," 23 dificultando ainda mais o enquadramento segundo o critério em voga.

Dentro desse viés, de acordo com o art. 511 e seus parágrafos da CLT, o trabalhador terceirizado teria como referência para o enquadramento sindical a atividade econômica exercida pela prestadora. Entretanto, a referida filiação, conforme Lívia Miraglia, pode "representar um contra-senso, tendo em vista o fato de os obreiros efetivamente laborarem dentro da empresa tomadora." 24

Além desta nuance, a terceirização provoca, pelo seu caráter, como bem assinala Delgado, "a pulverização da mão-de-obra entre as diversas empresas tomadoras de serviços, dificultando a formação de um sindicato forte e coeso." 25 Dentro dessa perspectiva, conforme Lívia Miraglia, “os sindicatos representantes da categoria profissional dos trabalhadores terceirizados são quase sempre mais fracos que os sindicatos das empresas tomadoras e, possuem, portanto, menor poder de barganha e negociação diante das empresas prestadoras." 26

Nesta linha reflexiva, o enquadramento sindical do trabalhador terceirizado assume peculiar relevo na discussão referente à representatividade sindical, a qual

\footnotetext{
21 SILVA (2008a, p. 234)

22 MIRAGLIA (SD, p. 3125)

23 VIANA (2003, p. 3)

24 DELGADO (2008, p. 471)

25 DELGADO (2008, p. 471)

26 MIRAGLIA (SD, p. 3127)
} 
será observada, ao longo do trabalho, sob a perspectiva constitucional, denunciando o anacronismo do princípio da unicidade em face dos avanços democráticos da Constituição. 


\subsection{O problema do enquadramento sindical dos trabalhadores terceirizados}

As mutações na forma de produzir têm desvirtuado as clássicas relações de emprego, desafiando a dimensão jurídica a criar novas formas de garantir a proteção do trabalhador. ${ }^{27}$ Ocorre que a exacerbação da competitividade nos mercados tem exigido empresas mais dinâmicas e flexíveis, imprimindo, desta forma, a necessidade de potencializar ao máximo a redução de capitais fixos, incluindo-se neles, a força de trabalho.

Assim, ao tentar enxugar a forma de produzir, numa frenética busca por redução de custos, o mercado tem optado por formas das mais diversas para empregar a força obreira, tentando, sempre, desvincular-se de qualquer obrigação trabalhista. Disso resulta a diversificação das formas jurídicas de emprego, dentre as quais, tem-se por destaque, a terceirização.

Deste modo, segundo ensinamento de Noemia Porto, "a classe trabalhadora não pode mais ser considerada como sinônimo do proletariado industrial produtivo; pois ela, nesse novo contexto, o transcende [...]." 28

O detalhe a ser verificado, segundo o texto supracitado, é que a classe trabalhadora perde a sua característica de homogeneidade, passando a figurar nas mais variadas formas. Esta heterogeneidade do trabalho, como registra Noemia Porto, “é fator não só de aumento de complexidade do mundo do trabalho, como também serve para demonstrar a pluralidade que emerge da sociedade contemporânea." 29

Nesse contexto, costuma-se apontar para a gestação de um novo modo de produzir, ainda em processo de definição, numa espécie de transição entre o velho e o novo modo de produzir. ${ }^{30}$ Entretanto, parece mais coerente dizer, como assinala Viana, "que o novo modelo seja exatamente essa mistura. Nesse sentido, é importante notar como as novas empresas se interagem com as velhas e mesmo com o mercado informal, articulando, produzindo e controlando a diversidade." 31

\footnotetext{
${ }^{27}$ SILVA (2008a, p. 122)

${ }^{28}$ NOEMIA PORTO (2010, p. 86)

${ }^{29}$ NOEMIA PORTO (2010, p. 86)

${ }^{30}$ VIANA (2003, p. 30)

${ }^{31}$ VIANA (2003, p. 30)
} 
O trabalho, nesse sentido, conforme propugna Noemia Porto, "passa a ser desenvolvido com mesclas do modo de produção anterior e do modo de produção emergente." 32 Deste modo, diante das antigas e novas práticas de empregar, o trabalho passa a ser marcado pela transitoriedade, pelas mudanças constantes, tornando-se mais flexível para se adaptar as constantes demandas das novas formas de produzir. Nesse sentido, vale lembrar as palavras de Viana, segundo o qual "até a natureza dos vínculos de trabalho, hoje, é flexível e cambiante, pois a empresa pode se valer indiferentemente de um autônomo, de um estagiário ou de um empregado, para alcançar o mesmo resultado.” 33

Tal configuração apresenta uma problemática muito séria, pois, se esta hipótese estiver correta, conforme Viana, "a solução do problema será ainda mais difícil," pois, segundo ele "não teremos no futuro apenas uma forma de trabalhar, nem um só modelo de empresa, mas uma multiplicidade crescente." 34

Em face disso, segundo Viana, "o Direito do Trabalho terá de ser flexível de modo a acompanhar tais transformações." ${ }^{35}$ Ou seja, o direito trabalhista precisará flexibilizar a forma de enquadramento dos novos fenômenos do trabalho, a fim de fazer valer o princípio de proteção ante as investidas precarizantes do capital sobre o trabalho.

Esta necessidade se dá, na visão de Sayonara Grillo, pela percepção de que "a mobilidade, a volatilidade do capital e a flexibilidade laboral ampliaram [e podem ampliar ainda mais] a capacidade empresarial de exercer pressões e maior controle do trabalhador." 36 Sendo que, paralelo a este quadro, conforme ainda consigna Sayonara, "registra-se o enfraquecimento generalizado da capacidade e do poder de atuação sindical." 37

Deste modo, vale colocar em relevo, consoante verificação de Noemia Porto, que, "como é próprio à complexidade contemporânea, as novidades que conferem outros contornos ao mundo do trabalho não tem origem única, ou uma única causa explicativa, ao contrário, compõem um plexo de acontecimentos e razões." ${ }^{38}$ Nesta visão, Noemia Porto, ainda, assevera que “embora não seja possível esgotá-los, alguma visão perspectiva sobre eles é imprescindível para uma reflexão crítica acerca do grau de afetação

\footnotetext{
${ }^{32}$ NOEMIA PORTO (2010, p. 86)

${ }^{33}$ VIANA (2003, p. 30)

${ }^{34}$ VIANA (2003, p. 30)

35 VIANA (2003, p. 30)

${ }^{36}$ SILVA (2007, p.30)

${ }^{37}$ SILVA (2007, p. 30)

${ }^{38}$ NOEMIA PORTO (2010, p. 86)
} 
sobre a concepção que vinha sendo construída sobre o trabalho como questão social, e não como mera mercadoria." 39

Desta forma, consoante Domingues e Teodoro, "a crise do Direito do Trabalho apresenta duas conseqüências principais, que são também as suas principais necessidades atuais: a precarização e a dificuldade de sindicalização." ${ }^{40}$ Assim, este trabalho propugna, com base nos argumentos expostos, que a terceirização, como forma de erosão dos direitos dos trabalhadores, ${ }^{41}$ combinada com o enquadramento sindical brasileiro, em seu sentido principiológico da unicidade, acaba por gerar, dentre os efeitos maléficos que produz, a pulverização dos trabalhadores com a consequente falta de representatividade dos sindicatos.

A constatação disso exige o entendimento de como se dá o fenômeno da terceirização na organização sindical, para que, por conseguinte, se compreenda a dimensão restrita imposta pelo princípio da unicidade, que, combinada com aquela, acaba por dificultar a sindicalização no Brasil.

A primeira observação a ser feita sobre a terceirização, neste propósito, está no fato de ela formar uma relação trilateral, em que o trabalhador terceirizado exerce suas atividades na planta de uma empresa, mas seu empregador é outro. ${ }^{42}$ Sendo assim, nas palavras de Viana, “em termos de Direito do Trabalho, a terceirização desafia não só o princípio protetor, mas o próprio conceito de empregador, visto que "há um sujeito que admite e assalaria e um outro que efetivamente dirige." 43

Percebe-se, com isso, que o sindicato do trabalhador terceirizado não é o mesmo dos companheiros de trabalho, sendo que, conforme Domingues e Teodoro, "tal situação desarticula a união dos trabalhadores, o sentimento de classe, a possibilidade de organização política e de reivindicação, [...] Ademais, demonstram o problema estrutural dos sindicatos e a consequente falta de representatividade [...]" 44

\footnotetext{
${ }^{39}$ NOEMIA PORTO (2010, p. 90)

${ }^{40}$ DOMINGUES; TEODORO (2010, p. 77-78)

${ }^{41}$ THÉBAUD-MONY; DRUCK (2007, p. 29)

${ }^{42}$ DOMINGUES; TEODORO (2010, p.78)

${ }^{43}$ VIANA (2003, p. 2)

${ }^{44}$ DOMINGUES; TEODORO (2010, p.78)
} 
Ocorre que, segundo leciona Noemia Porto, "os laços de solidariedade que eram essenciais para a concepção inicial de sindicalismo foram rompidos com a dispersão do sentido tradicional de classe que a acompanhava." 45

Assim, embora haja um compartilhamento de boa parte das condições de trabalho, os trabalhadores terceirizados e permanentes, conforme Noemia Porto, "uns e outros não chegam a desenvolver objetivos comuns de oposição aos modos de produção capitalista, de organização da mão-de-obra e de articulação da força de trabalho definidas pelos empreendedores econômicos." 46

Para compreender melhor esta conjuntura, vale destacar as relações entre o sindicalismo e as duas forma de terceirização, quais sejam: interna e externa. Conforme Viana, "uma e outra são faces de um mesmo fenômeno e se refletem de uma mesma maneira nas relações de poder entre capitalistas e trabalhadores." 47

A terceirização interna, segundo Viana, se caracteriza quando a empresa "reaproveita parte dos trabalhadores expulsos, valendo-se de outra empresa, que os comercializa." ${ }^{48}$ A externa, por seu turno, na conceituação deste autor, "é quando a fábrica passa a gerir tudo - homens, máquinas, matéria-prima, produtos - através de outras empresas da rede." ${ }^{49}$ Em vista disso, Sayonara Grillo acrescenta que "na contemporaneidade há uma opacidade do empregador real, e uma fragmentação da representação do trabalho por força dos mecanismos de subcontratação [...]" 50

A constatação, segundo Viana, "é que a fábrica consegue produzir de forma dispersa e ao mesmo tempo sincronizada," ${ }^{51}$ isto é, organiza-se em rede. Assim, vale salientar que a terceirização não tem por objetivo, apenas, reduzir custos ou especializar a produção, mas, também, garantir-se contra os riscos com a flexibilidade em todos os níveis, inclusive de trabalho. ${ }^{52}$ No limite deste processo, conforme consigna Viana, "a empresa tende a se tornar mera gerenciadora de serviços, denominado por alguns como empresa vazia" 53

Em verdade, pode-se concluir, consoante Viana, que "a terceirização tornou-se uma necessidade. A empresa não tem como reunir dentro de si todas as etapas do

\footnotetext{
${ }^{45}$ NOEMIA PORTO (2010, p. 107-108)

${ }^{46}$ NOEMIA PORTO (2010, p. 107-108)

${ }^{47}$ VIANA (2003, p. 3)

${ }^{48}$ VIANA $(2003$, p. 9$)$

${ }^{49}$ VIANA (2003, p. 10)

${ }^{50}$ SILVA (2008b, p. 142-143)

${ }^{51}$ VIANA (2003, p. 10)

52 VIANA (2003, p. 10)

${ }^{53}$ VIANA (2003, p. 12)
} 
ciclo produtivo." ${ }^{54}$ Esta prática tem como consequência, além da precarização do trabalhador, a fragmentação do universo operário, sendo, um de seus matizes, o fato de os trabalhadores terceirizados não se integrarem aos permanentes, chegando tal relação, às vezes, a ser conflituosa. ${ }^{55}$

Sob essa perspectiva, o sindicato, na medida em que a fábrica se dissemina, sente dificuldade em recompor a unidade desfeita, isto é, perde a referência, o seu contraponto. ${ }^{56}$ Ocorre que hoje, segundo Viana, "os trabalhadores - especialmente os trabalhadores terceirizados - vagam no espaço e no tempo. Vão e voltam, passando do emprego ao desemprego, ao subemprego e a um novo emprego, numa relação de permanente curto-circuito." 57 O que a empresa faz, em verdade, conforme Viana, "é um duplo movimento. Ela expulsa o trabalhador protegido e o retoma sem proteção; seja através de terceirizações internas, como através das externas." 58

É neste movimento que a terceirização traz prejuízos e desajustes para o movimento sindical, pois ocasiona a fragmentação da classe trabalhadora no tempo e no espaço.

Nessa perspectiva, a terceirização interna é caracterizada quando uma empresa coloca dentro de si os trabalhadores de outra, na qual se tem por destaque a do trabalhador temporário, pois o curto tempo de cada contrato acentua um dos problemas da terceirização, notadamente no que se refere ao enquadramento sindical. Ocorre que ela dificulta a identidade de classe, visto que, embora se integre por alguns meses à empresa tomadora, o trabalhador não se insere na coletividade que a compõe. ${ }^{59}$

O processo de fragmentação implementado pela terceirização, como se pode ver, desagrega o movimento sindical, seja ela externa ou interna. Com efeito, conforme Domingues e Teodoro, "a terceirização traz ínsito ao seu desenvolvimento o grande incremento da pulverização de força de trabalho." 60

Nesta perspectiva, calha lembrar que a mencionada pulverização provocada pela terceirização tem como causa a falta de identidade comum. Assim, conforme

\footnotetext{
${ }^{54}$ VIANA (2003, p. 12)

${ }^{55}$ VIANA (2033, p. 18)

${ }^{56}$ VIANA (2003, p. 18)

${ }^{57}$ VIANA (2003, p. 19)

${ }^{58}$ VIANA (2003, p. 20)

${ }^{59}$ DELGADO (2003, p. 197)

${ }^{60}$ DOMINGUES; TEODORO (2010, p. 80)
} 
assinala Domingues e Teodoro, "a multiplicidade de tomadores de serviço, componentes de distintas categorias econômicas, bem como a sucessão dos contratos de trabalhos firmados pelos trabalhadores terceirizados, inviabiliza a agregação dos obreiros com nítidos interesses econômicos e de condições de trabalho comuns." 61

Assim, dada a confusão ocasionada pela terceirização, seja no seu matiz externo, ou interno; pergunta-se qual seria o melhor enquadramento sindical para os trabalhadores terceirizados?

Há quem defenda o enquadramento sindical de empregado de empresa prestadora de serviços na categoria a que estão vinculados os trabalhadores da empresa tomadora de serviços. Tal mecanismo, conforme Domingues e Teodoro, "garantiria direitos e condições de trabalho idênticos aos trabalhadores terceirizados e aos empregados diretos das empresas tomadoras de serviços, coibindo a terceirização ilícita e permitindo maior força integrativa às categorias de trabalhadores." 62

Ocorre que, no dizer de Domingues e Teodoro, é no contexto da empresa tomadora de serviços que se encontram as mesmas condições de trabalho:

No contexto da empresa tomadora de serviços, onde os trabalhadores atuam sob as mesmas condições de trabalho, que estarão presentes os critérios de similitude de condições existenciais, profissionais e econômicos que caracterizam determinada categoria. ${ }^{63}$

Não por menos a jurisprudência tem entendido ser correto $\mathrm{o}$ enquadramento sindical do empregado conforme a atividade preponderante/fim do empregador. Entretanto, tal critério só beneficia o trabalhador terceirizado quando se caracteriza a terceirização ilícita.

Ocorre que na hipótese de terceirização lícita, segundo as regras do ordenamento jurídico e nos termos do inciso III da Súmula n. 331, do TST, a atividade econômica prevalecente da empresa prestadora de serviços é que vai definir o enquadramento sindical do trabalhador terceirizado. Isto é, apenas quando for configurada a terceirização ilícita é que se terá a declaração de vinculo diretamente com o tomador.

Doutra parte, numa segunda corrente, propugna-se pela possibilidade de opção, por parte do obreiro, de escolher entre o sindicato da prestadora ou da tomadora,

\footnotetext{
${ }^{61}$ DOMINGUES; TEODORO (2010, p. 80)

${ }^{62}$ DOMINGUES; TEODORO (2010, p. 82)

${ }^{63}$ DOMINGUES; TEODORO (2010, p. 80)
} 
conforme melhor convier. Assim, pelo seu caráter dual, propugnam ser a melhor solução, inclusive, para o trabalhador terceirizado que se vincula por tempo curto a cada empresa, como temporário. ${ }^{64}$

Nessa moldura sistemática, as duas opções configuram avanço para os trabalhadores terceirizados, entretanto, resta lembrar que a configuração do enquadramento sindical é fruto do anacrônico princípio da unicidade, o qual restringe a liberdade sindical. A par disso, impende mencionar como terceira solução o enquadramento sindical livre, sem as restrições de categoria e base territorial, dando azo à liberdade sindical plena.

Veja-se que, conforme alinhavado linhas atrás, a terceirização aliada ao princípio da unicidade tem dificultado a sindicalização com representatividade, tornandose tal princípio um agravante desnecessário ao já complexo problema da terceirização no mundo do trabalho.

Ou seja, além do problema de conformação jurídica da terceirização, soma-se, nesse quadro, o do enquadramento sindical de trabalhadores por segmento de atividade do empregador, o qual aprofunda as dificuldades de coesão dos trabalhadores e pulveriza ainda mais sua integração.

A terceirização, como se pode ver, necessita de um procedimento mais flexível e dinâmico para poder dar ensejo à representação sindical, não podendo estar limitada, no já difícil e confuso processo de sindicalização, ao princípio da unicidade.

Sendo assim, deve-se abolir a limitação em relação ao trabalhador quando da escolha de seu sindicato, dando azo à liberdade sindical plena, conforme se aduzirá neste trabalho. Com a adoção da liberdade sindical, porém, o atual processo de enquadramento sindical se tornará sem sentido, pois a escolha será livre, isto é, de acordo com o interesse de determinada atividade laboral.

${ }^{64}$ DELGADO (2003, p. 185) 


\section{A liberdade sindical como direito fundamental}

\subsection{A liberdade sindical como direito fundamental: a democracia sindical como elevada taxa de complexidade social}

A primeira questão que se apresenta é como considerar a liberdade sindical como direito fundamental, visto ser inadequado, segundo a estruturação autopoiética do direito, deduzir o direito a partir de uma fonte externa. Com efeito, o seu fundamento em elementos externos bloquearia a autopoiese do sistema jurídico, visto ser este caracterizado pelo "encerramento operativo." 65

Impende mencionar, neste passo, conforme Clam, que a legitimidade é informada pela recursividade operativa do sistema, ou seja, "a legitimação do sistema jurídico é adquirida pela ficção legal de uma validade positiva de suas normas - mantida fora de toda referência axiológica." 66

Nestes termos, conquanto se consagre a liberdade sindical no sistema internacional como direito fundamental, ${ }^{67}$ tal consideração não pode servir de referência para o sistema jurídico brasileiro, dado que este, pelo princípio da legalidade, ainda não elevou a liberdade sindical ao status de direito fundamental em sua estrutura, não podendo, portanto, operar de forma recursiva em relação a ela nessa perspectiva.

Assim, a indagação a ser colocada em relevo é aquela segundo a qual se pergunta quais características tornam a liberdade sindical um direito fundamental.

Talvez a resposta esteja na correlação entre a "indeterminação positiva" dos direitos fundamentais, aduzida por Corsi, ${ }^{68}$ e a preferência do sistema jurídico, na perspectiva evolutiva, segundo Luhmann, pelo sentido mais abstrato. De início, Corsi já assinala:

A nossa suposição é de que esta estabilidade sem fundamentos, se assim podemos nos exprimir, alcançada mediante uma autoprogramação condicional desvinculada de vínculos externos, simboliza o próprio horizonte

\footnotetext{
${ }^{65}$ CLAM (2005, p.120)

${ }^{66}$ CLAM (2005, p.120)

${ }^{67}$ SILVA (2008, p. 88)

${ }^{68}$ CORSI (2001, p. 15)
} 
futuro mediante aquela "indeterminação positiva" característica das formulações modernas dos valores e dos direitos fundamentais. ${ }^{69}$

O conceito de indeterminação positiva revela a principal função da Constituição como aquisição evolutiva, que é positivar os direitos fundamentais de modo a tentar vincular, de forma irresistível, o futuro, ${ }^{70}$ ressaltando-se, com este fim, o progressivo esvaziamento semântico de seus valores, isto é, a "progressiva perda de referências reais." 71

Tais características atribuem aos direitos fundamentais em seu papel constitucional, segundo Corsi, "a intenção de se vincular o futuro mediante as constituições, transformando estas em uma "acumulação preventiva de futuro"." 72

Já na teoria dos sistemas, consigna-se, consoante Luhmann:

[...] que o direito moderno gera um medium de possibilidades não mais externo (natureza não decidível) mas interno (direito positivo, fruto de decisão), podendo fazê-lo graças a uma forma, a constituição, que contra toda tentativa ainda atual e contra todas as evidências, tem seu ponto de força em não prejulgar nada: uma forma sem forma. ${ }^{73}$

Este medium de possibilidades, vale indicar, guarda relação com conceito de sentido mais abstrato dos sistemas jurídicos. Sendo que, na concepção de Luhmann,

[...] as sociedades mais complexas necessitam crescentemente de premissas mais abstratas das expectativas para poderem permitir e legitimar estruturalmente mais amplas possibilidades em termos de expectativas e comportamentos. ${ }^{74}$

Assim, a necessidade de premissas mais abstratas das expectativas corresponde à função atribuída aos direitos fundamentais no constitucionalismo contemporâneo, dada a crescente complexidade da sociedade moderna.

A par disso, vale mencionar que as identificações de sentido, para Luhmann, “estão em um nível mais alto de abstração, pois são sínteses de várias expectativas, concretizáveis e particularizáveis conforme as necessidades." 75 Isto é, o direito, por se caracterizar como programa condicional, conforme Corsi, “não tem qualquer fim, limitando-

\footnotetext{
${ }^{69}$ CORSI (2001, p. 15)

${ }^{70}$ CORSI (2001, p. 12-13)

${ }^{71}$ CORSI (2001, p. 13)

72 ZAGREBELSKY apud CORSI (2001, p. 13-14)

${ }^{73}$ LUHMANN apud CORSI (2001, p. 15)

${ }^{74}$ LUHMANN (1983, p. 104)

${ }^{75}$ LUHMANN (1983, p. 97)
} 
se a estabelecer as condições que podem ser ativadas ou não, no futuro, de acordo com as circunstancias, caracterizando-se como programa condicional." 76

Dentro dessa perspectiva, assevera Luhmann;

[...] o sentido patrocina o encadeamento das expectativas, regula a passagem de uma expectativa para outra, a assimilação de experiências e desapontamentos no contexto das expectativas, a possibilidade de substituição de antigas por novas expectativas, e, também, o alcance da revogação da cadeia de expectativas no caso de desapontamentos, assim como o tipo e o tempo necessário das possibilidades de assimilação daí resultantes. ${ }^{77}$

Desta forma, a identificação em termos de sentido, segundo Luhmann, não pode se referir "a todas as expectativas, mas, apenas, a tipos abstratos que possam permanecer constantes, atuando como regras geradoras das diversas expectativas," ou seja, na sua concepção, “o controle da consistência estrutural só é possível com o auxílio das abstrações de sentido." 78

Nessa lógica, é possível perceber a correlação entre os tipos abstratos que possam permanecer constantes e a acepção moderna dos direitos fundamentais. Esta concatenação referente ao sentido dos sistemas revela que a evolução sistêmica ocorre na direção de concepções de sentido mais concretas para a de concepções de sentido mais abstratas, ${ }^{79}$ sendo este processo o vértice do presente texto, em que a adoção da liberdade sindical como direito fundamental é uma aquisição evolutiva do sistema no sentido de que o faz progredir abstratamente em termos de sentido.

Observe-se que tal ilação dá substrato à concepção de Corsi, segundo a qual há "progressivo esvaziamento semântico dos valores expressos," ${ }^{80}$ dado que, segundo ele, "a função dos direitos fundamentais não se identifica com o seu conteúdo normativo, mas sim com a representação de um futuro, ainda desconhecido, ao qual não são colocados limites naturais ou morais." 81

O processo de abstração do sentido no sistema jurídico, vale lembrar, ocorre no intento de preservar a manutenção da congruência normativa das expectativas

\footnotetext{
${ }^{76} \operatorname{CORSI}(2001$, p. 8$)$

${ }^{77}$ LUHMANN (1983, p. 97)

${ }^{78}$ LUHMANN (1983, p. 97)

${ }^{79}$ LUHMANN,(1983, p. 179)

${ }^{80}$ CORSI (2001, p. 1$)$

${ }^{81} \operatorname{CORSI}(2001$, p. 1$)$
} 
sociais. ${ }^{82}$ Este processo é desencadeado de forma a reagir às pressões que o ambiente imprime ao sistema jurídico. ${ }^{83}$

Diante disso, vale consignar, conforme assinala Luhmann, que "o princípio de desenvolvimento são as crescentes complexidades e contingência da sociedade,” ${ }^{84}$ sendo que, a partir deste pressuposto, as estruturas do direito sofrem pressão no sentido de mudança. ${ }^{85}$ Observe-se que, para Luhmann, "a nova teoria dos sistemas sociais aponta para uma abordagem a partir da complexidade dos sistemas sociais e suas relações com o ambiente," o que evidencia, nas referidas relações, um suposto efeito regulador da evolução. ${ }^{86}$

Nesta sistemática, faz-se necessário lembrar que o direito, enquanto sistema, atua de forma a reduzir a complexidade do ambiente, resultando, daí, em maior complexidade interna. Entretanto, nas palavras de Luhmann,

$$
\begin{aligned}
& \text { No contexto da sociedade podem existir sistemas sociais capazes de } \\
& \text { resguardar-se da pressão da crescente complexidade sem se tornarem } \\
& \text { relevantemente mais complexos [...], por meio de técnicas específicas de } \\
& \text { adaptação. }{ }^{87}
\end{aligned}
$$

À vista dessa circunstância, o direito pode primar pelos direitos fundamentais como conteúdo essencial da Constituição, aceitando-os como técnica específica de adaptação, isto é, o direito fundamental é adotado como "um princípio sistêmico de alta complexidade que é generalizado, abrindo-se muitas possibilidades de adaptação que possam ser utilizadas em qualquer parte da sociedade." 88

Esta seria, por exemplo, como se propugna neste trabalho, a fundamentação da adoção do princípio da liberdade sindical plena como princípio sistêmico de alta complexidade. Tal consideração propiciaria mais possibilidades de adaptação do sistema jurídico e, consequentemente, das expectativas organizacionais sindicais.

Esta concepção torna evidente a indispensabilidade de vacuidade semântica dos valores e princípios, pois, segundo Corsi:

[...] todo valor ou direito fundamental tem o sentido de abrir um espaço de contingência completamente indeterminado, no interior dos quais os aparatos

\footnotetext{
${ }^{82}$ CLAM (2005, p.129)

${ }^{83}$ CLAM (2005, p. 129)

${ }^{84}$ LUHMANN (1983, p. 172)

${ }^{85}$ LUHMANN (1983, p. 172)

${ }^{86}$ LUHMANN (1983, p. 171)

${ }^{87}$ LUHMANN (1983, p. 172)

${ }^{88}$ LUHMANN (1983, p. 172-173)
} 
organizacionais e os seus procedimentos internos podem especificar determinadas formas. ${ }^{89}$

O fato é que a linha geral da evolução estrutural está na condição de que "se as conquistas evolutivas devem ser estabilizadas, então as estruturas devem permitir mais ações," 90 ou seja, devem compatibilizar-se melhor com a diversidade social, permitindo maior liberdade do agir. ${ }^{91}$

Nessa perspectiva, a Constituição, como bem lembra Corsi, mostra-se como "instrumento admirável, capaz de reduzir e, portanto, aumentar a complexidade alcançável pelo sistema jurídico," ${ }^{92}$ dando ensejo a diversas possibilidades de se construir o por vir. ${ }^{93}$

Na visão de Luhmann, "a crescente multiformidade da vida social acaba por mudar a contingência e a complexidade dos campos de interação do comportamento cotidiano." ${ }^{94}$ Bem por isso, este consigna que deve ser possibilitado "o estabelecimento de sínteses de sentido compatíveis com a complexidade de visão de mundo e do sistema social, oferecendo, então, mais possibilidades de opção." 95

Dentro dessa lógica, a concepção sintética do sentido coaduna com a postura de constitucionalização do direito, aduzindo, desta forma, a liberdade sindical como princípio mais compatível com a complexidade sindical. Veja que é necessário, portanto, segundo Corsi, "um grau de indeterminação tal que permita deixar aberto, constantemente, um horizonte de possibilidades, isto é, disponível em relação a um futuro que é, ainda, desconhecido e imprevisível." 96

Tal constatação corresponde ao esvaziamento semântico dos direitos fundamentais, que, no dizer de Corsi, na "evolução de tais direitos, resta evidente que sua generalização, certamente social, mas também temporal, é possível apenas com os custos de seu esvaziamento." 97

Dadas as proposições, é possível notar que o direito passa, evolutivamente, do sentido concreto para o sentido abstrato, sendo a dimensão do concreto-

\footnotetext{
${ }^{89}$ CORSI (2001, p. 10)

${ }^{90}$ LUHMANN (1983, p. 173)

${ }^{91}$ LUHMANN (1983, p. 173)

${ }^{92}$ CORSI (2001, p. 11)

${ }^{93}$ CORSI (2001, p. 11)

${ }^{94}$ LUHMANN (1983, p. 173)

${ }^{95}$ LUHMANN (1983, p. 174)

${ }^{96}$ CORSI (2001, p. 11)

${ }^{97}$ CORSI (2001, p. 13)
} 
abstrato aspecto essencial da variação do processo evolutivo. ${ }^{98}$ Ou seja, a adoção de sentidos mais abstratos em detrimento de sentidos concretos é um aspecto evolutivo do sistema jurídico, segundo Luhmann.

Nessa perspectiva, faz-se mister aduzir, na visão de Luhmann, “que o sentido concreto é dependente do conteúdo imediato da experiências e das condições subjetivas da capacidade de percepção." 99 Ou seja, o sentido concreto tem por característica a tendência de confrontar a experimentação ofertando nenhuma ou poucas alternativas. ${ }^{100}$

Ao evoluir para a forma abstrata, no dizer de Luhmann, "o sentido passa a apresentar mais alternativas, e ao mesmo tempo ele se torna utilizável e independente do contexto." ${ }^{101}$ Assim, neste ponto, é possível perceber a correspondência entre a concepção abstrata do sentido e a concepção de indeterminação dos direitos humanos, ressaltando a utilidade do progressivo esvaziamento semântico destes, isto é, criando mais alternativas.

Ocorre que, como assinala Luhmann, "quem integrar suas expectativas de forma demasiadamente concreta, e mesmo assim normatizá-las, terá uma vida rica em desapontamentos e dificilmente irá assimilá-los.” 102 Resta claro, portanto, a necessidade de um grau mínimo de abstração do contexto das expectativas, a fim de se ter, na concepção de Luhmann, um “ordenamento menos atritivo possível das expectativas." 103

Nesse passo, Corsi consigna que a importância dos direitos fundamentais reside no "modo decisamente particular de representar-se a indeterminação daquilo que, no sistema do direito, é possível." ${ }^{104}$ Sendo assim, conforme este propugna, é mediante a constitucionalização que os "direitos fundamentais tornam-se símbolos de futuras diferenças, são unidades que têm sentido apenas como diferenças ainda desconhecidas e sobre as quais dever-se-á (eventualmente) decidir.” 105

Sendo assim, a Constituição, apesar da relativa improbabilidade da seu surgimento em determinado sistema jurídico, ${ }^{106}$ há a possibilidade de defendê-la como aquisição inevitável do sistema jurídico, pois este, a partir do recrudescimento da complexidade social, tende a sofrer pressões das expectativas sociais, caminhando sempre de

\footnotetext{
98 LUHMANN (1983, p. 179)

99 LUHMANN (1983, p. 179)

${ }^{100}$ LUHMANN (1983, p. 179)

${ }^{101}$ LUHMANN (1983, p. 180)

${ }^{102}$ LUHMANN (1983, p. 99)

${ }^{103}$ LUHMANN (1983, p. 99)

${ }^{104}$ CORSI (2001, p. 14)

${ }^{105}$ CORSI (2001, p. 14)

${ }^{106}$ CORSI (2001, p. 3)
} 
concepções mais concretas para as mais abstratas, visto que, conforme Luhmann, sociedades mais complexas exigem premissas mais abstratas.

Ou seja, a constituição não é fruto de uma norma superior, nem mesmo o seu conteúdo, os direitos fundamentais, estando sua legitimação pautada pelo modo seletivo de irritação entre os sistemas jurídico e político, conforme consigna Corsi:

[...] trata-se, aqui, de se considerar a constituição como o "acoplamento estrutural de direito e política", entendendo-se estes como dois diferentes subsistemas da sociedade atual. Com esta formulação - muito abstrata, como ocorre sempre quando se trata da teoria dos sistemas - pretende-se descrever a situação na qual dois sistemas são completamente autônomos e, mediante uma estrutura comum (no caso, a constituição), especificam de modo extremamente circunscrito e seletivo as possibilidades de "se irritarem" reciprocamente. ${ }^{107}$

Do esposado, portanto, conclui-se que o direito fundamental consubstancia-se como sentido do sistema jurídico em grau mais abstrato, sendo a seleção desta forma forçada pela necessidade de manter-se a congruência normativa das expectativas sociais. Ou seja, não há norma superior de validação dos direitos fundamentais, mas, apenas, a seleção improvável de um sentido mais abstrato como regra mais útil para contrastar a complexidade social. Esta dinâmica é que vai aduzir a importância do Constituição no ordenamento jurídico e no seio social.

Diante destas colocações, o presente trabalho apresenta o paradoxo (conflito) existente no art. 8 da Constituição Federal, em que se ressalta, mormente, o embate entre o princípio da liberdade sindical e o princípio da unicidade.

A par desse conflito, ou paradoxo, o sistema jurídico deve atuar de forma a resolvê-lo, mesmo que tenha por conseqüência novos conflitos. Tal processo de resolução informa, segundo Luhmann, "a adaptação do sistema jurídico à evolução social e ao aumento de sua diferenciação interna." 108

O fato é que, segundo Campilongo, "o direito é um domesticador de conflitos, devendo prevê-los e evitá-los." 109 Entretanto, afirma este que o direito "ao reconhecer o caráter jurídico de circunstâncias inéditas e não rotinizadas, o direito acaba por se autotransformar em mecanismo de considerável incremento da possibilidade de conflito." ${ }^{110}$ Nessa concepção, Campilongo assevera que "a função do direito é aquela de

\footnotetext{
${ }^{107}$ CORSI (2001, p. 3)

${ }^{108}$ LUHMANN apud CAPILONGO. (2002, p. 130)

${ }^{109}$ CAPILONGO (2002, p. 128)

${ }^{110}$ CAPILONGO (2002, p. 129)
} 
reconhecer os conflitos e, quando pode, produzir conflitos e empenhar sua própria complexidade para tentar resolvê-los." 111

Desta forma, o direito não pode ser produto dos interesses, devendo, antes, operar em termos autorreferenciais, como reflexo reativo dos conflitos sociais, bem como daqueles gerados na estrutura do próprio sistema jurídico. ${ }^{112} \mathrm{Ou}$ seja, conforme Campilongo, "o direito resolve conflitos, de um lado, e multiplica conflitos de outro," 113 num verdadeiro processo de paradoxalização e desparadoxalização.

Estes conflitos paradoxais do direito devem ser resolvidos por mecanismos de "desparadoxação". ${ }^{114}$ Deste modo, o crescimento do sistema jurídico passa a ser o resultado de uma recursiva correção dos seus problemas, numa espécie de desmontagem do paradoxo (conflito); não significando, entretanto, sua eliminação, já que estes tendem sempre a reaparecer, sob outras formas. ${ }^{115}$

Ocorre que, segundo Luhmann:

O motor da evolução é a crescente complexidade da sociedade, que torna mais sensível a discrepância nas diversas dimensões da generalização, exigindo, em conseqüência, uma atuação mais eficiente no sentido da generalização congruente, ou seja, da seletividade mais rigorosa, levando, com isso, a um grau mais elevado de sua especialização nesta função. Dessa forma a evolução do direito pode ser observada por meio de suas condições à complexidade da sociedade $[\ldots]^{116}$

Vale lembrar que "o direito é imprescindível enquanto estrutura, porque, sem a generalização congruente de expectativas comportamentais normativas, os homens não podem orientar-se entre si, não podem esperar suas expectativas," ${ }^{117}$ ou seja, a estrutura do direito deve ser institucionalizada tendo por perspectiva a sociedade, modificando-se, portanto, de forma a corresponder, em termos de complexidade, à complexidade social. ${ }^{118}$

Esta constatação, como já informou este trabalho, evidencia a necessidade de o sistema jurídico brasileiro evoluir no sentido de reduzir a complexidade que se encontra o quadro sindical brasileiro, adotando-se por fundamento de sentido orientador a liberdade sindical, consagrando-a como direito fundamental do trabalhador.

\footnotetext{
111 LUHMANN apud CAPILONGO. (2002, p. 128)

112 CAPILONGO (2002, p. 129)

113 CAPILONGO (2002, p. 129)

114 CAPILONGO (2002, p. 129)

115 CAPILONGO (2002, p. 129)

116 LUHMANN (1983, p. 122)

117 LUHMANN (1983, p. 170)

118 LUHMANN (1983, p. 170)
} 
Nesse sentido, Luhmann aduz que na evolução dos sistemas complexos é necessário a ação conjunta de três mecanismos:

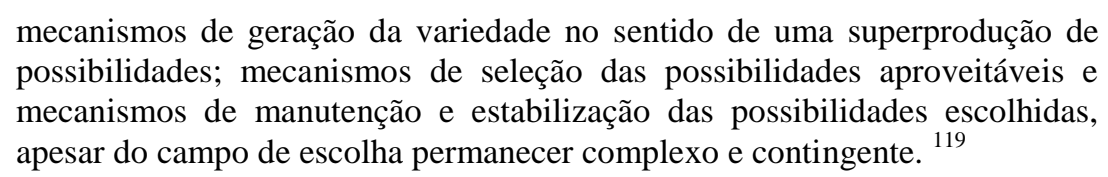

É de se realçar, nesta descrição, a autonomia do direito em relação à sociedade por meio da separação entre expectativas cognitivas e normativas, tendo destaque, para fins deste trabalho, o fato de que a estrutura de definições de sentido assume representações mais abstratas no lugar de noções mais concretas. ${ }^{120}$ Daí ser adequado consagrar o princípio da liberdade sindical, por ser mais abstrato, em detrimento do princípio da unicidade, pois, como bem enfatiza Corsi, "a função dos princípios e dos valores consiste em abrir espaço para uma enorme quantidade de vínculos e de diferenças." 121

Veja que as premissas estruturais da formação do direito tendem, em face da superprodução de expectativas sociais, a um grau de abstração maior a fim de abarcarse maior número de possibilidades dessas expectativas, como forma de minorar os desapontamentos. É nesse sentido que ganha relevo a inserção dos direitos fundamentais nas cartas constitucionais.

É por este motivo que, consoante acentua Corsi, há, por parte da sociedade, várias tentativas de se tornar indeléveis, pelos textos constitucionais, certos valores. ${ }^{122}$ Neste ponto, o mesmo autor consigna que "a referência a estes em uma lei que se reputa fundamental revela a intenção de vincular-se o futuro de modo irreversível, tendo-se em mente, freqüentemente, um passado cujo retorno se pretende evitar." ${ }^{123}$

Assim, a liberdade sindical plena como premissa de sentido mais abstrata serve para manter a alta complexidade do direito. ${ }^{124} \mathrm{Ou}$ seja, pode-se aduzir que a adoção da liberdade sindical como direito fundamental em face da liberdade restrita, mais concreta, coaduna com a proposta de Luhmann, segundo o qual "as identificações de sentido,

\footnotetext{
${ }^{119}$ LUHMANN (1983, p. 175)

${ }^{120}$ LUHMANN (1983, p. 176)

${ }^{121}$ CORSI (2001, p. 12)

${ }^{122}$ CORSI (2001, p. 12-13)

${ }^{123}$ CORSI (2001, p. 12-13)

${ }^{124}$ LUHMANN (1983, p. 179)
} 
com as quais expectativas concretas são geradas no direito, têm que ser abstraídas para poderem captar um número maior de possibilidades mais variadas." 125

Ocorre que, conquanto se consagre a liberdade sindical no caput do art. $8^{\circ}$ da Constituição Federal, resta consignar que está não corresponde à concepção de direito fundamental aduzida por Corsi, visto ter por limite o princípio da unicidade, elencado no art. $8^{\circ}$, inciso II.

O princípio da liberdade sindical, portanto, mostra-se restrito, dando azo à conformação mais concreta, isto é, com menos possibilidade de agir, menos alternativas. Esta configuração, ocasionada por este paradoxo, tende a reduzir a complexidade social, tornando as forma de organização sindical menos demoncrática, dada a prevalência do princípio da unicidade e seu estreito processo de enquadramento sindical.

Nesse sentido, a liberdade sindical plena, que nega o princípio da unicidade, mostra-se mais correlato com o sentido abstrato, servindo melhor aos anseios da base de sustentação do sindicalismo, os trabalhadores. Dentro dessa perspectiva, o princípio da unicidade guarda relação com o sentido concreto, pois confronta a experimentação e a ação com nenhuma ou poucas alternativas, dado que são oferecidas poucas possibilidades aos trabalhadores no que tange à prática sindical.

Assim, a forma mais abstrata do sentido que informa a liberdade sindical, como se pode ver, resultará em mais possibilidades de integração, de modo a acomodar mais expectativas normativas. Isto é, a Constituição, enquanto norma programática, só terá a consolidação de sua eficácia quando fizer valer seu espectro principiológico, do que se deduz a necessidade de um processo de seleção que dê substância prática à liberdade sindical.

A problemática da liberdade sindical, portanto, aduz a relevância de se a ter como preceito fundamental da dignidade do trabalhador. Pois, se assim constituído, a liberdade sindical plena, como nova forma de tutela laboral, passa assegurar recurso de poder às representações coletivas dos trabalhadores, dando-lhes a liberdade necessária para lutar pelo aprimoramento contínuo de seus direitos.

Assim, a liberdade sindical, alçada ao plano constitucional, passa a instituir um sistema de proteção ao trabalhador, baseado na valorização da liberdade e da

${ }^{125}$ LUHMANN (1983, p. 179) 
autonomia sindical. Nessa perspectiva, conforme Sayonara Grillo, "estabelece-se um sistema em que a liberdade sindical deixa de ser um mero valor desprovido de juridicidade, passando a figurar como princípio que visa a potencializar a capacidade de ação coletiva." 126

Esta configuração jurídica, como se observa, contribui para que o direito não perca sua dimensão garantista, fazendo prevalecer a justiça social. Desta forma, alçar a liberdade sindical ao status de direito fundamental dará poder de expressão ao trabalhador, para que este, ou estes, em suas relações interdependentes, possam recrudescer a taxa de complexidade de forma a aumentar a pressão sobre o sistema jurídico.

Destarte, dentro dessa perspectiva, o processo decisório deve ter por substrato, ou critério de sentido, a liberdade sindical como princípio fundamental, extinguindo elementos normativos que dificultem a sua fruição. Sendo assim, o art. $8^{\circ}$ da Constituição Federal deveria ser reformado pelo constituinte derivado de modo a garantir a liberdade sindical plena.

O que se deve ter em mente é que o princípio da unicidade destoa dos grandes avanços da Constituição, dificultando a articulação sindical em torno das demandas dos trabalhadores. Tal dispositivo, portanto, engessa a massa operária na luta por seus direitos, por um trabalho mais decente. Assim, no intuito de democratizar a prática sindical, deve-se desarraigar, dado o seu anacronismo, o princípio da unicidade do texto Constitucional, a fim de torná-lo mais adequado ao Estado Democrático de Direito. ${ }^{127}$

$\mathrm{O}$ aspecto relevante em se considerar a liberdade sindical como direito fundamental está no fato de os direitos fundamentais serem indeterminados, mais correlatos com a perspectiva abstrata do sentido do sistema jurídico, ou seja, mais aptos a lidar com o crescente número de expectativas sociais por permitir uma taxa maior de complexidade social.

Sendo assim, no que tange às práticas sindicais, a liberdade sindical propiciará, por parte do sistema jurídico, conforme Campilongo, um aumento de alternativas de escolha para os trabalhadores, ensejando maiores possibilidades de democracia. Estas maiores possibilidades de escolha para o trabalhador acabará por desfigurar o atual processo de enquadramento sindical, dado que a unicidade não fará qualquer sentido em face da liberdade de escolha.

\footnotetext{
${ }^{126}$ SILVA (2008b, p. 143-144)

${ }^{127}$ LOURENÇO FILHO (2008, p.135)
} 
Nesse sentido, Corsi assevera que:

Aquilo que as constituições especificam concretamente como direitos fundamentais é dado por contraste em relação às alternativas que permanecem indeterminadas e que, talvez, sejam efetivamente indeterminadas. Neste sentido, os direitos fundamentais não fundam o direito, mas o abrem em relação a um futuro que nenhuma "norma fundamental" pode antecipar. ${ }^{128}$

Nesse ponto, vale lembrar as palavras de Pereira de que a relativa amplitude material dos direitos fundamentais os tornam mais utilizáveis para o sistema jurídico, "pois quanto mais genéricos são seus textos, mais concreta é a probabilidade de abarcar um número maior de titulares e de contemplar um amplo espectro de situações tuteladas." 129

Pela lógica, portanto, o excesso de especificação do princípio da unicidade desfigura a liberdade sindical enquanto direito fundamental, visto que, com fulcro neste, estatui-se regras de enquadramento sindical enrijecedoras, produzindo contradição insuperável e incompatível com a posição que se pretende alçar a liberdade sindical. ${ }^{130} \mathrm{~A}$ figura do sindicato único, portanto, não é conciliável com a liberdade sindical, pois esta não comporta demasiado detalhamento, impedindo sua realização como direito fundamental. ${ }^{131}$

À vista dessas nuances, impende verificar a premente necessidade de se dar efetividade à liberdade sindical, dando-lhe a feição de direito fundamental, incrustandoa efetivamente no texto constitucional. Ou seja, deve-se evoluir no aspecto de dar vazão ao anseio trabalhista de liberdade, pois sem ela, o trabalhador irá sucumbir, no que tange ao espectro normativo, para uma verdadeira supressão de seus direitos.

A liberdade sindical, neste viés, é o grande ideal a ser buscado, vez que é mais concordante com a democracia o direito de os trabalhadores organizarem e constituírem livremente suas coalizões, segundo a conveniência de seus interesses. ${ }^{132}$

Neste passo, como bem enfatiza Kaufmann, resta claro que "as organizações representativas de trabalhadores devem ter ampla liberdade para se estruturar, conforme seus interesses se apresentem legítimos e conforme estratégias livremente eleitas para defendê-los." 133 Soma-se a isso o critério da "cindibilidade" dos interesses

\footnotetext{
${ }^{128}$ CORSI (2001, p. 16)

${ }^{129}$ PEREIRA. (SD)

${ }^{130}$ PEREIRA. (SD)

${ }^{131}$ PEREIRA. (SD)

${ }^{132}$ KAUFMANN (2010, p. 100)

${ }^{133}$ KAUFMANN (2010, p. 100)
} 
representados, que é, na verdade, como bem assinala Kaufmann, "a possibilidade de que um grupo de trabalhadores representados por um determinado sindicato se divida conforme seus interesses mais específicos." 134 Tal concepção mostra-se, como se pode ver, totalmente discordante com a conformação jurídico trabalhista da unicidade, pois se defende para os grupos minoritários o direito de liberdade de coalizão própria, segundo os seus interesses. ${ }^{135}$

Disso se deduz que os laços de solidariedade devem ser pautados pelos interesses dos trabalhadores, e não por critérios espaciais ou de categoria, consagrados na legislação. Ou seja, no Estado Democrático de Direito, deve-se reconhecer aos trabalhadores, em detrimento do resquício de paternalismo que se possa ter, a sua capacidade de autodeterminação. ${ }^{136}$

Nessa direção, o ordenamento jurídico deve reconhecer, também, a existência de grupos minoritários, assegurando-lhes condições de se organizarem, inclusive, em sindicatos, dando condições de exprimir interesses mais específicos em determinado tempo. Observe-se, portanto, que tal construção perpassa a efetiva garantia na Constituição da liberdade sindical como direito fundamental. ${ }^{137}$

Veja-se que está em discussão uma concepção mais democrática do sindicalismo brasileiro, tendo por fundamento a liberdade sindical como direito fundamental. Neste desiderato, é ângulo merecedor de reflexão a definição de democracia aduzida por Campilongo, a qual pode ser definida:

[...] como a manutenção de uma sempre elevada taxa de complexidade social, de uma sempre elevada taxa de alternativas de escolha; quanto mais amplas as alternativas de escolha, quanto mais abertas as alternativas de escolha, maiores as possibilidades de democracia. É isto democracia: manter elevada a complexidade social. ${ }^{138}$

Note-se que, conforme se propugna neste trabalho, os direitos fundamentais exercem papel absolutamente essencial neste aspecto, pois figuram como garantia dessa alta taxa de complexidade. ${ }^{139}$ Assim sendo, a relevância em se considerar a liberdade sindical como direito fundamental concerne-se ao fato de esta garantir alta taxa de complexidade no seio sindical, dando-o feições mais democráticas.

\footnotetext{
${ }^{134}$ KAUFMANN (2010, p. 100-101)

${ }^{135}$ KAUFMANN (2010, p, 100-101)

${ }^{136}$ LOURENÇO FILHO (2008, p.129)

137 LOURENÇO FILHO (2008, p.128)

${ }^{138}$ CAPILONGO (2002, p. 114)

${ }^{139}$ CAPILONGO (2002, p. 114)
} 
Ver a unicidade pelo ângulo da liberdade sindical como direito fundamental possibilita verificar como aquela, pela imposição do sindicato único, reduz a taxa de complexidade social. A impressão que se tem dos efeitos da unicidade é a mesma de Campilongo, qual seja: “a redução da complexidade é ausência de democracia." 140

Calha assinalar, em desfavor da unicidade, que a redução da complexidade importa em abolição dos direitos fundamentais. ${ }^{141} \mathrm{E}$ é justamente este ponto que desfavorece a aplicação do princípio da unicidade, visto que a imposição do sindicato único impede a alta taxa de complexidade do movimento sindical.

Veja-se, portanto, que o enrijecimento da estrutura organizacional dos sindicatos, por meio do princípio da unicidade, acaba por torná-la em estruturação antidemocrática, revelando, por oportuno, a necessidade de revigorá-la sob a égide do direito fundamental da liberdade sindical.

Esta ilação informa que a grande contribuição do sistema jurídico para o sistema político seja a de fornecer instrumentos que permitam à democracia manter sempre abertas as possibilidades de escolha, conforme aduz Campilongo:

Talvez a grande contribuição do sistema jurídico, a prestação do sistema jurídico para o sistema político seja exatamente esta: a de fornecer os instrumentos, a de viabilizar os mecanismos que permitam à democracia manter sempre abertas as possibilidades de escolha. ${ }^{142}$

Sendo assim, tratando-se de forma perfunctória, umas das formas de consagrar a liberdade sindical como direito fundamental, de forma a viger plenamente no ordenamento brasileiro, é selecionando a possibilidade disponível, qual seja: a ratificação da Convenção 87 da Organização Internacional do Trabalho.

A par dessas colocações, portanto, tendo por fundamento a liberdade sindical como direito fundamental, consigna-se a necessidade premente de intervenção evolutiva do constituinte derivado, a fim de efetivá-la.

Outro destaque a ser feito é que o reconhecimento da liberdade sindical plena implica na reestruturação dos processos decisórios trabalhistas, visto que a concepção de livre escolha, propiciada pela sua introdução, acabará por problematizar o efeito erga omnes das convenções coletivas, bem como permitir a substituição processual dos

\footnotetext{
${ }^{140}$ CAPILONGO (2002, p. 114)

141 CAPILONGO (2002, p. 114)

142 CAPILONGO (2002, p. 114)
} 
trabalhadores a nível inferior da antiga base territorial. Assim, embora de um lado se dificulte o efeito progressista do Direito do Trabalho, de outro, incrementa a complexidade, dando condição mais representativa aos trabalhadores de figurar nos tribunais em defesa de seus direitos. 


\subsection{A liberdade sindical como fator de representatividade e de dinamismo reivindicativo dos trabalhadores terceirizados.}

Em meio à crise que se instalou no mundo do trabalho, ganha relevo, como se viu neste trabalho, a terceirização como prática de marginalização do trabalhador de seus direitos. A terceirização, vale lembrar, acabou por imprimir uma transformação muito radical das relações de trabalho, dificultando, por seu turno, a sindicalização.

Diante desse quadro, a falta de liberdade sindical exsurge como agravante no processo de precarização do trabalho, notadamente no que se refere ao problema do enquadramento sindical dos trabalhadores terceirizados, denunciando uma crise do modelo sindical existente.

Nestes termos, ao perquirir quais as restrições advindas da terceirização, vale consignar que parte dos problemas sindicais, como bem assinala Sayonara Grillo, está "nos critérios utilizados para a organização sindical e o enquadramento pela atividade do empregador e na pouca utilização, pela jurisprudência, de concepções mais livres e voluntárias $[\ldots]^{\prime \prime} 143$

Uma das dificuldades está em identificar o empregador real, ${ }^{144} \mathrm{em}$ virtude do modelo trilateral de relação socioeconômica, culminando na fragmentação da representação do trabalhador terceirizado.

Desta forma, o problema acaba se deslocando para outras esferas, quais sejam: os critérios adotados para a organização sindical e o enquadramento sindical, já que a autonomia coletiva trabalhista é estreitamente dependente da configuração das organizações coletivas.

Vale lembrar que a terceirização, em sua perspectiva trilateral, "introduz um trabalhador na planta de uma empresa, em que seu empregador é outro, e seu sindicato não é o mesmo dos colegas de trabalho." ${ }^{145}$ Note que esta realidade empobrece o atual modelo de enquadramento sindical, retirando sua representatividade. Assim, por não corresponder às necessidades dos trabalhadores, tal sistemática encontra-se obsoleta no que

\footnotetext{
${ }^{143}$ SILVA (2008b, p. 143)

${ }^{144}$ SILVA (2008b, p. 143)

${ }^{145}$ DOMINGUES; TEODORO (2010, p. 78)
} 
diz respeito à capacidade de luta pelos direitos trabalhistas, figurando mais como um mecanismo de controle da massa operária.

Veja-se que a terceirização desarticula a união dos trabalhadores, retirando-lhes o sentimento de solidariedade e, por conseguinte, a possibilidade de organização política e de reivindicação; comprometendo seriamente o modelo de organização sindical existente. ${ }^{146}$

Deste modo, segundo Delgado, "doutrina e jurisprudências trabalhistas devem procurar enquadrar juridicamente o fenômeno social da terceirização no sentido de sua harmonização possível aos fins e valores essenciais do Direito do trabalho." 147 Sendo que, para tanto, faz-se necessário valorizar os princípios que despontam com força normativa constitucional, dentre os quais se destaca, no quesito enquadramento sindical, a liberdade sindical.

O fato é que o trabalho apresenta-se sobremaneira diversificado, desvirtuando a tradicional concepção de relação de emprego. Desta forma, a referida complexidade do ambiente trabalhista acaba por refletir no problema estrutural dos sindicatos, prejudicando sua função representatividade e reivindicativa.

Ou seja, além do problema de conformação jurídica da terceirização, soma-se, nesse quadro, o do enquadramento sindical de trabalhadores por categoria profissional tendo por critério a atividade preponderante do empregador. $\mathrm{O}$ fato é que a conciliação destes dois fatores aprofunda as dificuldades de se ter um sindicato representativo.

Outro aspecto a ser confrontado é o papel desempenhado pela jurisprudência, visto predominar nela o entendimento restritivo em relação à liberdade sindical, utilizando poucas concepções que direcione o sindicalismo para conformações mais livres. $^{148}$

Exemplo dessa direção é a recente decisão do Tribunal Superior do Trabalho, em que, por maioria, a Seção Especializada em Dissídio Coletivo (SDC) decretou a ilegitimidade ad causam do sindicato (Sindimina) em face dos empregados de empresas prestadoras de serviço. ${ }^{149}$ Veja-se que o tratamento dispensado aos trabalhadores terceirizados

\footnotetext{
${ }^{146}$ DOMINGUES; TEODORO (2010, p. 78)

${ }^{147}$ DELGADO (2008, p. 437)

${ }^{148}$ SILVA (2008b, p. 143)

${ }^{149}$ TST, Processo: RODC-38800-81.2004.5.20.0000
} 
destoa, de forma muito grave, do que preceitua o texto constitucional referente à liberdade sindical, no qual se valorizou preceitos corporativos da antiga organização tradicional.

Ocorre que, conforme Sayonara Grillo, "um dos maiores fatores de preservação do sistema e esvaziamento das inovações anunciadas por ocasião da Constituinte são as interpretações construídas sobre o texto constitucional aprovado." ${ }^{150}$ Tal ilação, portanto, pode ser comprovada no julgado supracitado, em que se optou por adotar critérios oriundos do sistema corporativista precedente.

Vale destacar que a controvérsia, no Tribunal Superior do Trabalho, acabou por cingir-se a questão da SINDIMINA deter ou não legitimidade para representar, em dissídio coletivo de natureza econômica, os empregados de cinco empresas terceirizadas. ${ }^{151}$ Ou seja, a SDC, em outras palavras, teve que decidir entre a adoção do princípio da liberdade sindical ou da unicidade, optando por este último.

O que fica claro neste caso, inicialmente, é a falta de representatividade dos trabalhadores terceirizados em questão, os quais, pela necessidade, acabam por recorrer ao sindicato dos trabalhadores do tomador de serviços, corroborando posição inicial aventada por Lívia Miraglia. ${ }^{152}$

Destarte, a questão da representatividade acaba por se tornar o cerne do embate jurídico mencionado, tornando o caso emblemático no que tange à contradição entre os princípios da liberdade sindical e da unicidade. Assim, conforme palavras do ministro Fernando Eizo Ono, "tais princípios constitucionais balizam a controvérsia a respeito da representatividade e enquadramento sindicais, [...] a fim de se determinar a legitimidade $a d$ causam do sindicato profissional suscitante." Isto é, o problema da representatividade dos trabalhadores terceirizados perpassa, necessariamente, a contradição constitucional, sendo mais acertada, em favor desta, garantir a aplicação do princípio da liberdade sindical.

Desta forma, conquanto a SDC tenha considerado que o sindicato não é parte legítima para propor o dissídio suscitado no TRT da $20^{\mathrm{a}}$ Região, ${ }^{153}$ vale consignar os argumentos expendidos por este tribunal quando decidiu pela legitimidade do referido sindicato.

\footnotetext{
${ }^{150}$ SILVA (2008a, p. 235)

${ }^{151}$ TST, Processo: RODC-38800-81.2004.5.20.0000

${ }^{152}$ MIRAGLIA (p. 3127)

${ }^{153}$ TST, Processo: RODC-38800-81.2004.5.20.0000
} 
O TRT-SE, neste intento, ao decidir pela legitimidade ad causam, teve por premissa determinar qual sindicato melhor representaria os trabalhadores terceirizados no contexto da descentralização do processo produtivo. Nessa perspectiva, optou-se pela legitimidade ad causam do SINDIMINA, visto que os trabalhadores trabalhavam dentro do complexo minerador da Vale, lado a lado com os trabalhadores permanentes. ${ }^{154}$

Ou seja, o TRT levou em consideração a peculiaridade dos trabalhadores terceirizados, destacando a inadequação do atual processo de enquadramento sindical. Veja-se, portanto, que a decisão do TRT observou o que é informado pelos princípios constitucionais da proteção do trabalhador e da liberdade sindical em detrimento do princípio da unicidade, demonstrando ser possível o entendimento conforme o princípio da liberdade sindical, segundo propugna Sayonara Grillo. ${ }^{155}$

Nesse sentido, vale destacar excerto do tópico referente à legitimidade ad causam, em que o TRT-SE rejeita a preliminar:

No entanto, o critério da atividade preponderante da empresa não contempla a hipótese dos autos em face das peculiaridades da prestação do serviço realizado pelos trabalhadores. A requerente ao contratar com a Vale não prestou um simples serviço de engenharia o que estaria compatível com o seu objeto social (fl. 875), uma vez que, seus empregados prestaram serviço em condições ambientais e riscos inerentes à atividade de mineração. ${ }^{156}$

O que se apresenta é que a atual sistemática, conforme entendimento exarado, não contempla as peculiaridades dos trabalhadores terceirizados, demonstrando sua inadequação. Desta forma, a sistemática de enquadramento sindical para os trabalhadores terceirizados deveria ser outra, mais conforme com dinâmica da subcontratação.

Note-se que, no mesmo sentido, o ministro Fernando Eizo Ono, ao optar pela ilegitimidade ad causam na SDC, pontuou como "tormentosa" a questão do enquadramento sindical dos trabalhadores terceirizados:

Assim, conquanto tormentosa a questão do enquadramento sindical dos
empregados das empresas prestadoras de serviço, diante da legislação
sindical infraconstitucional, anterior ao surgimento do fenômeno da
terceirização, porém, como visto, recepcionada pelo atual texto
constitucional, o enquadramento sindical desses empregados terceirizados
segue a regra geral aplicável aos demais empregados, já que não se inserem
na exceção prevista no referido $\S 3^{\circ}$ do art. 511 da CLT. Portanto, a definição
ocorre a partir da atividade preponderante desenvolvida pelo empregador, na

${ }^{154}$ TST, Processo: RODC-38800-81.2004.5.20.0000

${ }^{155}$ SILVA (2008b, p. 232)

${ }^{156}$ TST, Processo: RODC-38800-81.2004.5.20.0000 
hipótese, as empresas prestadoras de serviço, e não a tomadora dos serviços. $^{157}$

Ou seja, mesmo diante das dificuldades e peculiaridades dos trabalhadores terceirizados, o TST os trata como se iguais fossem, ferindo, além do princípio da liberdade sindical, o princípio da igualdade material, pois desconsidera as flagrantes diferenças entre uns e outros.

Assim, no caso sob exame, resta evidente o quão pernicioso e anacrônico tem sido a aplicação do princípio da unicidade, visto cercear objetivo essencial da organização sindical, qual seja: a representatividade.

Neste passo, cabe aduzir que o TRT, no fundamento da rejeição da preliminar de ilegitimidade ad causam, consignou o seguinte pensamento:

[...] indaga-se: que tipo de sindicato melhor representaria os trabalhadores numa economia de mercado? Tomando como base que o presente dissídio visa compor conflitos coletivos de natureza econômica para melhorar e até igualar as condições de trabalho de quem presta serviço juntamente sob as mesmas condições, apesar de estarem sob subordinação de empresas distintas, reconhece-se a legitimidade da parte autora. [...] O que se observa no caso em exame é que as atividades dos empregados das empresas terceirizadas ora suscitadas fazem parte da atividade econômica de extração e beneficiamento de minério do potássio e trabalham dentro do complexo minerador da Companhia Vale do Rio Doce, lado a lado com os trabalhadores dessa empresa. ${ }^{158}$

Nesse mesmo sentido, o TRT-SE, para fundamentar sua tese, cita o

seguinte excerto:

Percebe-se do parecer de fls. 1393/1402 que, se por um lado o representante do Ministério Público entende pela ilegitimidade do autor, por outro, reconhece a lucidez do reconhecimento do vínculo do obreiro ao sindicato da categoria profissional correspondente à empresa tomadora do serviço. Isso porque nas palavras do Procurador do Trabalho, tal entendimento -permitiria, (...) a padronização de condições de trabalho em uma mesma empresa", como também que se trata de dar tratamento "isonômico e favorável aos trabalhadores das prestadoras" (fls.1393/1402). Reportando-se, ainda, ao parecer do Ministério público, é inegável reconhecer a subversão de valores perpetrada. De forma clara, o Parquet elege as questões técnicas para adoção das condições adequadas ao trabalho como motivo para ilegitimidade da parte ativa sobrepondo tal circunstância ao princípio da isonomia na garantia de direitos trabalhistas. ${ }^{159}$

Disso se deduz que o atual processo de enquadramento sindical, ao privilegiar questões técnicas (princípio da unicidade), torna-se avesso à realidade, não atendendo aos reclames dos trabalhadores comuns, tanto mais os terceirizados. Ou seja, como

\footnotetext{
${ }^{157}$ TST, Processo: RODC-38800-81.2004.5.20.0000

${ }^{158}$ TST, Processo: RODC-38800-81.2004.5.20.0000

${ }^{159}$ TST, Processo: RODC-38800-81.2004.5.20.0000
} 
pretende o entendimento do TRT-SE, o objetivo precípuo a orientar a aplicação das normas trabalhistas deve ser o da proteção ao trabalhador, dando condições de um trabalho mais decente. Nesse sentido, ciente da urgência social da questão, o TRT-SE exara:

Apesar de o Tribunal Superior do Trabalho ter editado a Súmula 331, em detrimento do que estava expresso no então Enunciado $n^{\circ} 256$, não quer dizer que se deva fechar os olhos para a realidade social e os direitos sociais constitucionalmente garantidos, posto que, como se poderia entender o desenvolvimento de uma sociedade justa e solidária? ${ }^{160}$

Nesta ótica, tendo em vista a situação dos trabalhadores terceirizados, mostra-se inadequado, segundo informa o princípio da liberdade sindical, o presente critério de enquadramento sindical. Consolida-se, por sua vez, a necessidade de o Poder Judiciário implementar as conquistas constitucionais no sentido da liberdade sindical, favorecendo concepções mais livres de enquadramento dos trabalhadores nos sindicatos. Assim, partindo desse prisma, calha defender a liberdade sindical plena, garantindo-a na Constituição, a fim de preservar as reais reivindicações dos trabalhadores, dando expressão mais representativa.

Em lado oposto ao propugnado, no caso sob exame, nas razões do recurso ordinário, a Companhia Vale do Rio Doce, ao renovar a arguição de ilegitimidade ad causam, alegou que a corte Regional, ao proferir o acórdão recorrido, "ignorou os preceitos contidos nos arts. 511 da CLT, $8^{\circ}$, II e III e 114, §2º da Constituição Federal, baseando sua decisão naquilo que acreditava ser justo e razoável, porém sem respaldo legal.” 161

É apropriado observar, nestes argumentos, que o entendimento do TRT-SE é encarado como desprovido de respaldo legal, baseado na equidade do justo e razoável, tornando pertinente a observação de Sayonara Grillo da necessidade de estabelecer "um sistema em que a liberdade sindical deixa de ser um simples valor desprovido de juridicidade, para se impor como um princípio que visa potencializar a capacidade de ação coletiva, com o objetivo de desarmar o autoritarismo presente nas relações entre capital e trabalho." 162

Por esta razão, pode-se dizer que o atual enquadramento sindical não abarca os interesses dos trabalhadores terceirizados, tornando-se a resolução de tal questão premente quando se discute a garantia de direitos trabalhistas e as condições decentes de trabalho. Propõe-se, assim, o enquadramento sindical livre, conforme o princípio

\footnotetext{
${ }^{160}$ TST, Processo: RODC-38800-81.2004.5.20.0000

${ }^{161}$ TST, Processo: RODC-38800-81.2004.5.20.0000

${ }^{162}$ SILVA (2008b, p. 143-144)
} 
constitucional da liberdade sindical, como instrumento de inclusão dos trabalhadores terceirizados nas discussões trabalhistas, por meio da atuação e representação sindical.

Desta forma, a consagração da liberdade sindical plena exsurge como necessidade premente de democratização das práticas sindicais. Ocorre que este preceito, em sua concepção abstrata e indeterminada, em face do princípio da unicidade, possibilita mais opções de escolha, atendendo melhor a complexidade do mundo sindical.

Nesse aspecto, o enquadramento sindical livre dos trabalhadores terceirizados mostra-se fundamental, sob pena de esvaziarem-se, para estes, as garantias de atuação sindical expressamente consignadas como direitos sociais no art. $8^{\circ}$ da Constituição Federal.

Assim, com base no exemplo citado, e nas constatações anteriores, é possível concluir pela necessidade de uma nova sistemática interpretativa do Direito Coletivo do Trabalho, notadamente no que se refere ao enquadramento sindical, de forma a propiciar o fortalecimento do sindicalismo. Esta postura será, seguramente, "mais um passo rumo à efetivação dos direitos sociais do trabalho insculpidos no texto constitucional, reconhecendoos como direitos humanos fundamentais." ${ }^{163}$.

Assim, sustenta-se a necessidade de se garantir no texto constitucional a liberdade sindical como direito fundamental, a fim de se ter uma maior representatividade dos sindicatos em face dos trabalhadores terceirizados, dinamizando a sua função reivindicativa.

\footnotetext{
${ }^{163}$ KAUFMANN (2010, p. 103)
} 


\section{Conclusão}

O mundo do trabalho mostra-se altamente complexo e inapreensível, no qual se afigura, de forma gradual, a deterioração da rede de proteção trabalhista. Isto é, o mundo capitalista, pela exacerbação da competição, tem imprimido seu ritmo ao mundo do trabalho, desarticulando e enfraquecendo suas organizações.

A par disso, é possível perceber quão pernicioso e deletério tem sido este ritmo ao mundo trabalhista, em que se fez, neste trabalho, destaque ao fenômeno da terceirização. Tal enfoque teve por intento demonstrar que a terceirização acentua e aglutina os maiores percalços por que vem passando o mundo do Trabalho, transformando-se no maior desafio ao sindicalismo.

Veja que tal fenômeno tem por característica principal a marginalização do trabalhador terceirizado das garantias trabalhistas tão arduamente conquistadas ao longo do desenvolvimento capitalista, caminhando este, por conseqüência, rumo à marginalização social.

Assim, o direito trabalhista não pode ficar inerte ante a precarização do trabalho; pois as incertezas e riscos do mercado, a partir da concepção de socialização dos riscos, não devem ser suportados, apenas, pelo obreiro, mas sim serem compartilhados, segundo as condições de cada ente social. O que não tem ocorrido, já que o trabalhador vê-se, sempre, impotente diante dos ditames do capital, submetendo-se a condições de trabalho expropriantes, no que concerne a direitos.

O tema não é de fácil resolução, e talvez nem chegue a uma formulação tal que se enquadre toda a sistemática que envolve o mundo do trabalho, já que este está em constante mudança. Ou seja, o dinamismo do mundo exige posturas dinâmicas para estabilizar transformações em curso e expectativas de comportamentos futuros. Sendo assim, no caso trabalhista, o dinamismo econômico e social exige um direito dinâmico, capaz de dar respostas rápidas e efetivas às novas demandas que se apresentam a todo instante.

Nessa perspectiva, o Direito do Trabalho precisa evoluir, em termos de complexidade, juntamente com o seu ambiente, a fim de não se transformar em mero instrumento artificial, sem correspondência com a realidade. Neste intento, o enquadramento sindical do trabalhador terceirizado assume peculiar relevo na discussão referente à representatividade sindical, ainda mais quando contrastado com o princípio da unicidade. 
Ocorre que os interesses perseguidos pela organização sindical são específicos a determinados grupos, sendo que a perseguição destes deve ser assegurada pela mais ampla liberdade, restando claro que o primeiro limite a ser vencido é o do princípio da unicidade, valorizando, em face dele, a liberdade sindical plena.

Sob esta perspectiva, resta denunciar que o enquadramento sindical de trabalhadores terceirizados por segmento de atividade do empregador aprofunda as dificuldades de coesão e pulveriza ainda mais a sua integração, colocando em questão a atuação e a representação sindicais dos trabalhadores terceirizados.

A terceirização, portanto, precisa de um procedimento mais flexível e dinâmico para poder dar ensejo à representação sindical, isto é, um sindicato mais plástico, não podendo estar limitada, no já difícil e confuso processo de sindicalização, ao princípio da unicidade.

Sendo assim, deve-se abolir a limitação em relação ao trabalhador quando da escolha de seu sindicato, dando azo à liberdade sindical plena. Sendo importante perceber que o atual processo de enquadramento sindical, com a adoção da liberdade sindical plena, se tornará sem sentido, pois a escolha será livre, pautado apenas pelo interesse do trabalhador.

Outro ponto a destacar é que o princípio da unicidade configura-se como elemento antidemocrático no seio sindical, pois o engessa, diminuindo a complexidade social, e, por conseguinte, a fruição do direito fundamental da liberdade sindical. A par dessas colocações, portanto, tendo por fundamento a liberdade sindical como direito fundamental, consigna-se a necessidade premente de intervenção evolutiva do constituinte derivado, a fim de efetivá-la, dando, assim, novo ar ao processo de conformação sindical, diverso do atual enquadramento.

Neste objetivo, uma das formas de consagrar a liberdade sindical como direito fundamental, de forma a viger plenamente no ordenamento brasileiro, é selecionando a possibilidade disponível, qual seja: a ratificação da Convenção 87 da Organização Internacional do Trabalho, extirpando do ordenamento constitucional o pernicioso e deletério princípio da unicidade.

Registre-se, por último, que o critério de enquadramento sindical deve ser estabelecido pelos sindicatos, isto é, pelos órgãos formais, segundo os seus procedimentos, 
conforme propugna Corsi. Assim, estatuindo-se a liberdade sindical como direito fundamental, dado o seu conteúdo vazio, caberá aos trabalhadores terceirizados identificarem suas necessidades e interesses, delimitando o conteúdo normativo da liberdade sindical, a fim de se enquadrarem da forma mais representativa possível no mundo sindical. 


\section{REFERÊNCIAS BIBLIOGRÁFICAS}

ARAUJO PINTO, \& LOURENÇO Filho, Ricardo Machado. Entre a indisponibilidade e a negociação: as normas coletivas como fontes do direito do trabalho. In: Caderno Jurídico. 172 .Escola Judicial do TRT da $10^{\mathrm{a}}$ Região. Brasília, ano 3, volume 3, n. 4, p. 9-33, julho/agosto de 2009.

AQUINO, Leonardo Gomes. A liberdade Sindical. Artigo, 2004. disponível em: www.universojurídico.com.br. Consultado em novembro de 2011.

AUGUSTO, Ilnah Toledo. A autonomia coletiva privada diante da Constituição Federal/88: conflitos. Mestranda pela Unimep -Universidade Metodista de Piracicaba, 2006.

BALEStero, Gabriel Soares. A Autopoiese da Política e do Direito em Luhmann e o Papel do Julgador. S. / UNOPAR Cient., Ciênc. Juríd. Empres., Londrina, v. 11, n. 2, p. 47-56, Set. 2010

BENHAME, Maria Lucia. Liberdade Sindical Plena? Disponível em: WWW.benhame.adv.br, consultado em dezembro de 2011.

BRIDI, Maria Aparecida (org). O Sindicalismo equilibrista entre o continuísmo e as novas práticas. Curitiba: UFPR/SCHLA, 2006.

CARVAlHO, José Murilo de. Cidadania no Brasil: o longo caminho. 11 ed. Rio de Janeiro: Civilização Brasileira, 2008.

CARVALHO, Olavo de. Que é o direito? Seminário de Filosofia, 22 de setembro de 1998.

CHALMERS, Alan. O que é ciência afinal? Tradução: Ral Filker. Editora brasiliense, 1993. (p.123-133)

CONTINENTINO, Marcelo Casseb. Revisitando os Fundamentos do Controle de Constitucionalidade: uma crítica à prática judicial brasileira. Porto Alegre: Sergio Antonio Fabris Ed, 2008.

CORSI, Giancarlo. Sociologia da Constituição. Trad. Juliana N. Magalhães. Revista da Faculdade de Direito da Universidade Federal de Minas Gerais. N 39. Belo Horizonte: UFMG, janeiro-junho de 2001.

CAMPIlONGO, Celso Fernandes. O Direito na Sociedade Complexa. São Paulo : Max Limonad, 2000.

Política, Sistema Jurídico e Decisão Judicial. São Paulo: Max Limonad, 2002.

DELGADO, Maurício Godinho. Curso de direito do trabalho. 7. ed., São Paulo : Ltr, 2008.

DELGADO, Gabriela Neves. Terceirização - paradoxo do direito do trabalho contemporâneo. São Paulo: LTR, 2003.

DOMINGUES, Gustavo Magalhães de Paula Gonçalves; TEODORO, Maria Cecília Máximo. Alternativas para o Sindicalismo: o Enquadramento Sindical pela Atividade do Trabalhador ou do Tomador dos Serviços. Rev. TST, Brasília, vol. 76, no 2, abr/jun 2010.

DRUCK, Maria da Graça. Terceirização: (des)fordizando a fábrica. São Paulo: Boitempo Editorial, 2001.

ECKERT, Clarissa; MONTEIRO; Frabricio. O que há de complexo no mundo complexo? Niklas Luhmann e a Teria dos Sistemas Sociais. Sociologias. Porto Alegre. 2006. (p.182-207) Disponível em ww.scielo.br/pdf/soc, site consultado em novembro de 2011.

GIUGNI, Gino. Direito Sindical. Tradução Eiko Lúcia Itioka. São Paulo. LTr, 1991.

JUNIOR, Ruy Ferreira Mattos. Direitos Fundamentais e Direito de Liberdade. Revista Direitos Fundamentais e Democracia. volume 6, 2009. 
LOURENÇO FILHO, Ricardo Machado. Liberdade Sindical, Autonomia e Democracia na Assembléia Constituinte de 1987/1988 - Uma Reconstrução do Dilema entre Unicidade e Pluralidade. Dissertação de Mestrado apresentada ao Programa de Pós-Graduação em Direito da Faculdade de Direito da Universidade de Brasília, para obtenção do título de Mestre em Direito, Estado e Constituição. 2008.

LUHMANN, Niklas. Sociologia do Direito I/Niklas Luhmann; tradução de Gustavo Bayer. Rio de Janeiro: Edições Tempo Brasileiro, 1983.

MANGABEIRA, Wilma. Dilemas do novo sindicalismo: democracia e política em volta redonda. Tradução de Vera Pereira. Rio de Janeiro: Relume-Dumará: ANPOCS, 1993.

MIRANDA, Carlos Roberto. Ataque ao Mundo Do Trabalho: Terceirização e seus Reflexos Na Segurança e Saúde do Trabalhador. Disponível em: http://www.tst.gov.br. Consultado em novembro de 2011.

MIRAGLIA, Lívia Mendes Moreira. A Viabilização da Terceirização no Brasil. Disponível em: www.conpedi.org.br. Consultado em novembro de 2011.

NEVES, Marcelo. Entre Têmis e Leviatã: uma relação difícil: o Estado Democrático de Direito a partir e além de Luhmann e Habermas. Tradução do autor. São Paulo: Martins Fontes, 2006.

NEVES, Marcelo. A força simbólica dos Direitos Fundamentais. Revista eletrônica de direito do Estado. Bahia, 2005.

NIKLAS Luhmann: a nova Teoria dos sistemas/ Org. por Clarissa Eckert e Eva Machado-Porto Alegre: Universidade/UFRGS, Goethe-institut/ICBA,1997. (P.75-91)

NASCIMENTO, Amauri Mascaro. Direito Sindical, 2 ed. São Paulo: LTR, 1984.

KAUFMANN, Marcus de Oliveira. Da Formal Representação à Efetiva Representatividade Sindical: Problemas e Sugestões em Modelo de Unicidade. Rev. TST, Brasília, vol. 76, no 2, abr/jun 2010

KUROSAKA, Rafael. Liberdade Sindical e Sistemas de Organização Sindical. Dissertação. Pontifícia Universidade Católica de Goiás: Centro de Pós-graduação Lato Sensu:Curso de Especialização em Direito e Processo do Trabalho, 2010.

KUNZLER, Caroline. A teoria dos sistemas de Niklas Luhmann. Estudos de sociologia, Araraquara, 16, 2004. (p.123-136) Disponível em WWW.fclar.unesp.br/soc/revista/artigos, site consultado em novembro de 2011.

PEREIRA, Ricardo José Macedo de Britto. Liberdade Sindical como Direito Fundamental. Univ. Complutense de Madri.

PORTO, Noemia Aparecida Garcia. Desproteção Trabalhista e Marginalidade Social: (im) Possibilidades para um Trabalho como Categoria Constitucional de Inclusão. Dissertação de Mestrado apresentada ao Programa de Pós-Graduação em Direito da Faculdade de Direito da Universidade de Brasília. 2010.

RODRIGUES, Iram Jácome (org). O Novo Sindicalismo. Petrópoles; Editora Vozes, 1999.

ROCHA, Leonel Severo. Introdução à teoria do sistema autopoiético do Direito/ Leonel Severo Rocha, Germano Shwartz, Jean Clam. Porto Alegre: Livraria do advogado Ed. 2005.

SANTOS, Eduardo Barcelos dos. Enquadramento Sindical. SINDEAP/RJ. Disponível em: www.sindeaprj.org.br. Consultado em novembro de 2011.

SEVERO, Valdete Souto. A Constituição Federal e a Lente Invertida de quem Aplica o Direito do Trabalho. Artigo. TRT $4^{\mathrm{a}} \mathrm{R}-\mathrm{RS}$. Disponível em

SILVA, Sayonara Grillo Coutinho Leonardo da. Direitos Fundamentais e Liberdade Sindical no Sistema de Garantias: um Diálogo com Luigi Ferrajoli. Revista da Faculdade de Direito de Campos, Ano IV, No 4 e Ano $\mathrm{V}, \mathrm{N}^{\circ} 5$ - 2003-2004 pg. 303-323. 
Duas notas sobre novas tutelas laborais no multifacetado desenho do mundo do trabalho contemporâneo. In: Revista do Tribunal Superior do Trabalho, Brasília, vol. 74, $\mathrm{n}^{\mathrm{o}} 3$, jul/set 2008 (b), p. 121-148.

SILVA, Nívia Mônica da. Os impactos das relações intersistêmicas na concretização dos direitos fundamentais no Brasil / Nívia Mônica da Silva. - Belo Horizonte, 2010. 225 f. Orientador: Álvaro Ricardo de Souza Cruz. Dissertação (mestrado) - Pontifícia Universidade Católica de Minas Gerais, Programa de PósGraduação em Direito.

SILVA, Sidartha Sória. Reestruturação produtiva, crise econômica e os rumos do sindicalismo no Brasil. Brasília: Fundação Milton Campos, Conselho de Reitores das Universidades Brasileiras. 2001.

SINGER, Paul. Globalização e desemprego: diagnóstico e alternativas. 7. ed. São Paulo: Contexto, 2008. p. 49-50.

SHURMANN, Francisca Albertina. Sindicalismo e Democracia: o caos do Brasil e do Chile/Francisca Albertina Shurmann. Brasíla. Editora Universidade de Brasília, 1998.

SCHWARTZ, Yves. Trabalho e valor. In: Tempo social; Rev. Sociol. USP, São Paulo, 1996.

SCHWARTZ, Germano; João Hélio, Pasárgada e a formação de uma nova cultura jurídica no Brasil: problemas de alteridade e de direitos fundamentais desde a teoria dos sistemas sociais Autopoiéticos Revista Facultad de Derecho y Ciencias Políticas, Vol. 38, Núm. 109, julio-diciembre, 2008, pp. 481-499 Universidad Pontificia Bolivariana, Colombia.

STÜRMER., Gilberto. As relações coletivas de trabalho, a liberdade sindical e o poder normativo da Justiça do Trabalho. In: Âmbito Jurídico, Rio Grande, 52, 30/04/2008 [Internet]. Disponível em: www.ambito-juridico.com.br. Acesso em novembro de 2011.

THÉBAUD-MONY, Annie \& DRUCK, Graça. Terceirização: a erosão dos direitos dos trabalhadores na França e no Brasil. In: A perda da razão social do trabalho : terceirização e precarização / organização Graça Druck, Tânia Franco; autores Ângela Borges... [et al.]. São Paulo : Boitempo, 2007, p. 23-58.

TRINDADE, Édson Silva. Liberdade de Associação Sindical no Direito Brasileiro. Texto disponível em: bdjur.stj.gov.br Consultado em novembro de 2011.

VIANA, Márcio Túlio. Terceirização e sindicato: um enfoque para além do jurídico. In: Revista Ltr, São Paulo, ano 67, n. 7, julho de 2003, p. 775-790.

BRASIL. Tribunal Superior do Trabalho. RODC - 38800-81.2004.5.20.0000, Acórdão, Relator- Ministro Fernando Eizo Ono, publicado no Diário de Justiça de 24 de outubro de 2011; SDC/2011. RECURSOS ORDINÁRIOS. DISSÍDIO COLETIVO. SINDIMINA. REPRESENTAÇÃO DE EMPREGADOS DE EMPRESAS TERCEIRIZADAS. PRESTAÇÃO DE SERVIÇOS NO ÂMBITO DA COMPANHIA VALE DO RIO DOCE - CVRD. ILEGITIMIDADE ATIVA AD CAUSAM. 